rat

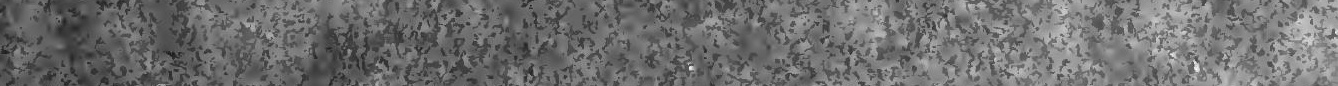
and

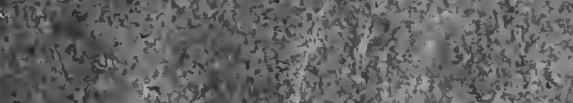
(3) 2.

(1)

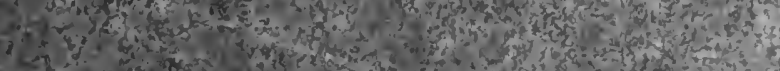

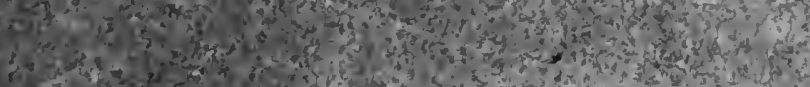

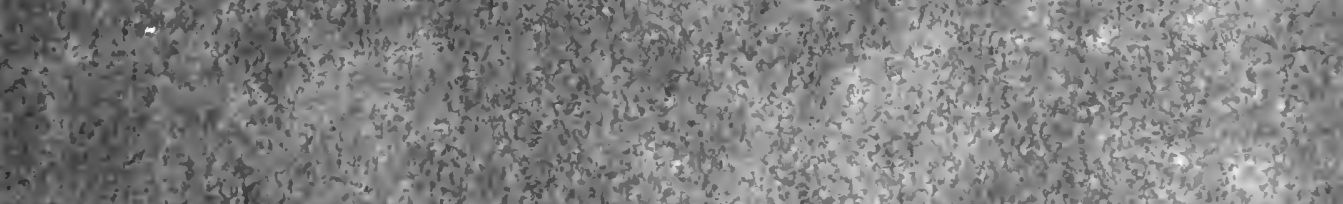

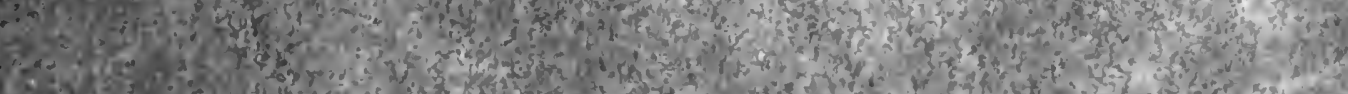

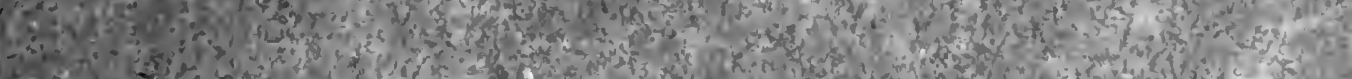

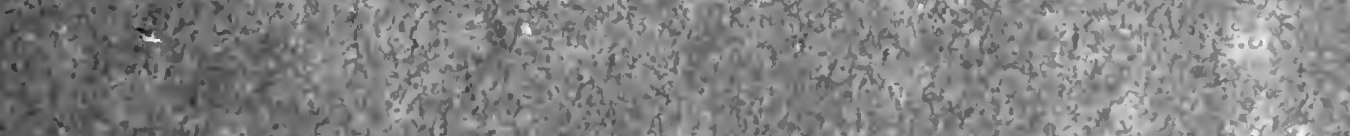




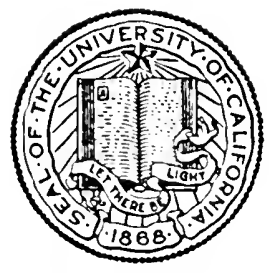

\section{THE LIBRARY OF}

THE UNIVERSITY OF CALIFORNIA LOS ANGELES 
Digitized by the Internet Archive in 2007 with funding from

Microsoft Corporation 



\title{
THE NEW POLITICS
}

\author{
AND OTHER PAPERS
}






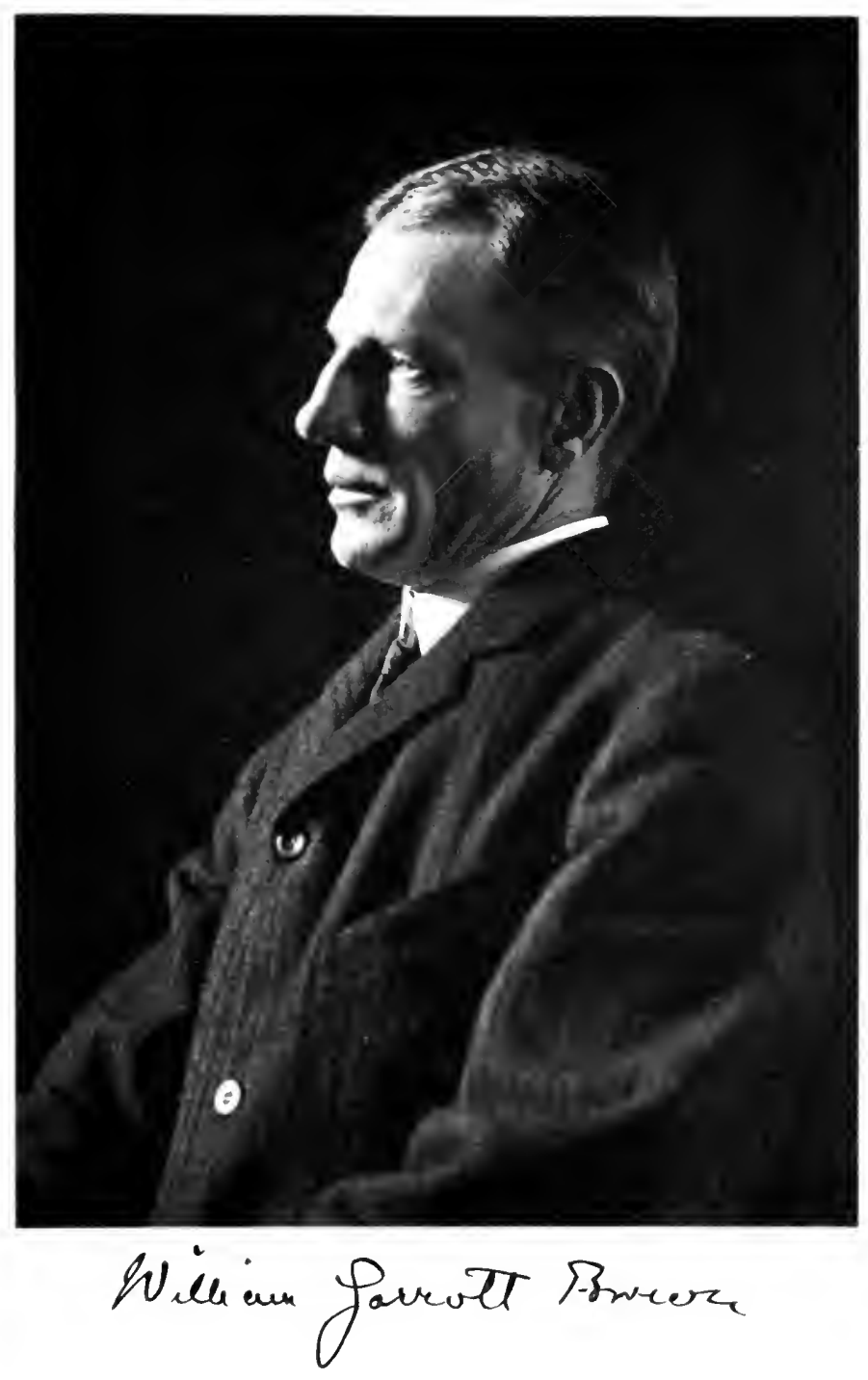




\title{
THE NEW POLITICS
}

\author{
AND \\ OTHER PAPERS BY \\ WILLIAM GARROTT BROWN
}

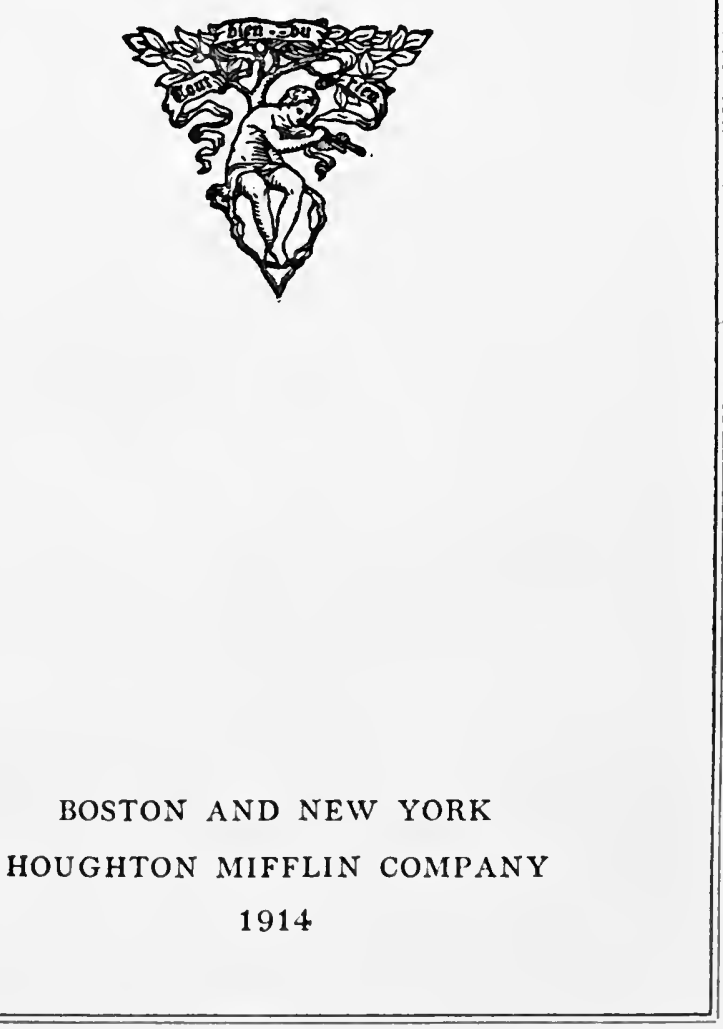


COPYRIGHT, 1914, BY EUGENE L. BROWN

ALL RIGHTS RESERVED

Published May ror4 


\section{College}

Library

$J K$

271

B 81 n

TO THE MEMORY OF

GROVER CLEVELAND 



\section{CONTENTS}

THE NEW POLITICS-

THE ISSUES • . . . . . . . . 3

PARTIES AND MEN . . . . . . . 30

PROPHETIC VOICES ABOUT AMERICA . 63

THE WHITE PERIL: THE IMMEDIATE

DANGER OF THE NEGRO . . . 103

THE SOUTH AND THE SALOON . . . I43

PRESIDENT TAFT'S OPPORTUNITY . . 163

GREETINGS TO THE PRESIDENTS-

TO THEODORE ROOSEVELT, MARCH 4, I909 . 197

TO WILLIAM H. TAFT, MARCH 4, 1909 . . 206

TO WILLIAM H. TAFT, MARCH 4, I9I3 . . 216

TO WOODROW WILSON, MARCH 4, I9I3. . 226 



\section{THE NEW POLITICS}




\title{
THE NEW POLITICS
}

\author{
I \\ THE ISSUES
}

10 a superficial view there is little in the
present state of our public affairs to suggest the notion of any marked transition. There are no wars or rumors of wars; even the prophecies and forebodings of that sort of excitement seem to lack conviction. They are but mildly lugubrious, and yield few shudders. Peace reigns - and prosperity, which is tamer still. Nor is there any "malice domestic" that looks particularly threatening. Sectional jealousies, though occasionally stirred, do not leap into flame. Party feeling, as between the two great parties, has seldom been so weak. Exciting and dramatic personal rivalries are equally wanting. There is nothing, for instance, to compare with the long confrontments of Jefferson and Hamilton, of Clay and Jackson, of Douglas and Lincoln. There is, indeed, a vigorous and heated struggle between two factions in one of the great parties, and the 


\section{THE NEW POLITICS}

two wings of the other great party may soon follow suit and favor us with a set-to; but neither division has as yet gone far enough to produce changes that can be regarded as clearly revolutionary.

But great changes in the political life of a people do not always come violently, dramatically. Some of the greatest have come, like those in nature, quietly. There is, I believe, a feeling among thoughtful men that such a change is in fact coming over our political life to-day; and very good reasons may be given for this view.

Twenty-two years ago, Mr. Bryce, coming to the end of his "American Commonwealth," had this to say about the future :-

America, in her swift onward progress, sees, looming on the horizon and now no longer distant, a time of mists and shadows, wherein dangers may be concealed whose form and magnitude she can scarcely yet conjecture. As she fills up her Western regions with inhabitants, she sees the time approach when all the best land will have been occupied, and when the land now under cultivation will have been so far exhausted as to yield scantier crops even to more expensive culture. Although transportation may also have then become cheaper, the price of food will rise; farms will be less 


\section{THE NEW POLITICS}

easily obtained and will need more capital to work them with profit; the struggle for existence will become more severe. And while the outlet which the West now provides for the overflow of the great cities will have become less available, the cities will have grown immensely more populous; pauperism, now confined to some six or seven of the greatest, will be more widely spread; wages will probably sink and work be less abundant. In fact, the chronic evils and problems of old societies and crowded countries, such as we see them to-day in Europe, will have reappeared on this new soil.

More than eighty years ago - that is to say, sixty years before Mr. Bryce's forecast - Macaulay, who never saw America, writing a reply to John Stuart Mill's essay on government, and controverting Mill's view that monarchies and aristocracies are always more rapacious than democracies, introduced this striking passage:-

Despots, we see, do plunder their subjects, though history and experience tell them that, by prematurely exacting the means of profusion, they are in fact devouring the seed-corn from which the future harvest of revenue is to spring. Why, then, should we suppose that the people will be deterred from procuring immediate relief and enjoyment by the fear of distant calamities - of calamities which perhaps may not be fully felt till the times of their grandchildren?... 


\section{THE NEW POLITICS}

The case of the United States is not in point. In a country where the necessities of life are cheap and the wages of labor high, where a man who has no capital but his legs and arms may expect to become rich by industry and frugality, it is not very decidedly even for the immediate advantage of the poor to plunder the rich; and the punishment of doing so would very speedily follow the offense. But in countries in which the great majority live from hand to mouth, and in which vast masses of wealth have been accumulated by a comparatively small number, the case is widely different. The immediate want is, at particular seasons, craving, imperious, irresistible. In our own time it has steeled men to the fear of the gallows, and urged them on the point of the bayonet. And, if these men had at their command that gallows, and those bayonets, which now scarcely restrain them, what is to be expected? Nor is this state of things one which can exist only under a bad government. . . Therefore, the better the government, the greater is the inequality of conditions; and the greater the inequality of conditions, the stronger are the motives which impel the populace to spoliation. As for America, we appeal to the twentieth century.

The twentieth century is upon us. Mr. Bryce named thirty years as the period which, in the opinion of the best judges, still intervened between the America he was writing about and the coming of the time when Americans would 


\section{THE NEW POLITICS}

find themselves confronted with the questions which had already long beset older and more crowded countries. That period is not yet exhausted; but the pace of our American advance has been accelerated. I think we can hardly doubt that certain new public issues which within the last two or three years have come very swiftly to the front are such as both Mr. Bryce in I 888 and Macaulay in 1829 foresaw that we should ultimately have to face; that they have come to stay; that the present time is therefore transitional - much more truly so than many periods which have seemed so mainly because they have been disturbed and exciting. We are not yet, it is true, an old society or a crowded country. But - the frontier is gone. With the admission of Arizona and New Mexico, the famous Senate Committee on Territories becomes a committee on Alaska alone. We are in the situation of a man who, though still very young, has nevertheless reached maturity and come into full possession of his estate; of an estate vast, indeed, vaster than that of any of his neighbors, - but yet of a vastness no longer incalculable, no longer 


\section{THE NEW POLITICS}

uncalculated, and which is also appreciably impaired by the waste and extravagance of his youth. We face, therefore, the duties and responsibilities of maturity, of a more careful development and husbandry of our great demesne. The time of boundless anticipation is past. We have, instead, a sure sense of strength, but with it comes also, at last, the sense that even our strength, and our capacity for growth, have their limits. There is as yet no real pinch, no hemming in, no severe pressure or congestion; far from it. But the certainty that these things are in the future is at last borne in upon us by facts and by wise warnings. That is enough, like the young man's first vivid confrontment with the mere knowledge of his limitations, to change our mood. Were we asked if our characteristic cheerfulness and hopefulness is not damped, we might still reply, "Not a jot, not a jot!" But we are indisputably taking up, and ought to be taking up, certain of the problems of "old societies and crowded countries"; and the coming of these new problems, these new issues, has somewhat changed the aspect of certain others which, even with us, are old. 


\section{THE NEW POLITICS}

There is much to hearten us as we enter upon the new epoch. As we turn to the questions, new and old, which now confront us, we can feel that certain other questions, certain whole classes of questions, in fact, which have at other times sorely tried free governments, do not now confront us at all. There are, for instance, the political troubles which have sprung from differences in religion - the very bitterest in history. It surely may be counted an immense triumph of democracy that these have for us practically ceased to exist. And it is so, too, with certain other fundamental things. Besides religious freedom, we have freedom of speech and of the press. Some very serious evils have, it is true, appeared in the press. It is badly commercialized. Its tone is frequently very low, and one does not, as a rule, find it governed by any high sense of responsibility. But it is still, as a whole, an invaluable safeguard. Whatever problems we have to face, we can discuss them with very great freedom. We obey Milton's injunction concerning Truth : "Give her but room, and do not bind her when she sleeps." In that alone is an immeasurable security and hope. To 


\section{THE NEW POLITICS}

say that we are also free from the political troubles and perplexities that spring from differences of race would be going too far. But I think we may say that those troubles and perplexities are to-day less acute, less threatening, less hampering and depressing, than they have ever been before. The sin and blunder of slavery is ended - is even, let us hope, atoned for. The mistake and wrong of Reconstruction is undone. Much, very much, remains to be done by way of adjustment, arrangement, education, justice ; but the temper in which we consider these things is vastly improved. I believe that most thoughtful men, if they should examine their own minds concerning this entire matter, would confess themselves more hopeful to-day than they have ever been - more hopeful than, a few decades ago, it seemed possible that they would ever be.

We can, therefore, turn to our new issues exceptionally free-handed, and with the good spirit that comes of substantial progress in free government.

The new issues all have this much in common: They are all at bottom economic, and eco- 


\section{THE NEW POLITICS}

nomic in a very strict derivative sense of the word - all questions of national housekeeping, of the safeguarding, the development, and the distribution of our immense national inheritance. John Sherman said long ago that nine tenths of the legislation of peace is the legislation of finance, and if finance be taken in its fullest meaning, that is truer to-day than when he said it. I am not sure that it has not also always been true; but the rapid and revolutionary development of the means, and the swift widening of the scale, of production and transportation - the marvelous extension of the principle of combination into every branch of industry and business - this change has transformed bewilderingly the entire field with which economic legislation must deal. It is not merely that we are approaching "the problems of old societies and crowded countries." Those problems have taken on for us new aspects, aspects hardly known elsewhere, and a truly American vastness of range. We can and should profit by a close study of European and Asiatic experience. The way we are at last coming to study that experience is perhaps the most 


\section{THE NEW POLITICS}

convincing, as it is the most natural, manifestation of our changing temper. But the guidance we can get from the older countries, however valuable, is limited. There are things we must work out for ourselves - in which we must ourselves be guides and pioneers; for the new industry, the new ways in business and finance, are much further advanced with us, and much more firmly established, than with the older peoples.

The particular new issue on which we can get the most guidance from Europe, and which is therefore the simplest of all, is that of conservation. To call that issue a question would be a misnomer. It is not a question at all - unless there is a question between economy and extravagance. To state it should be, so far as public opinion is concerned, to answer it. No one, I suppose, would have the hardihood to affirm that we ought to waste our patrimony instead of husbanding it, or that we ought to consume those natural resources which, like the forests and the soil's energy, are capable of self-maintenance and of increase, faster than they can be restored. The only question should be of ways and means, and 


\section{THE NEW POLITICS}

concerning these it will be some time before we exhaust the enlightenment to be got from European experience. The very recent date of the beginnings of scientific forestry among us is perhaps the best illustration of how much we can learn and must learn from that experience - and of how amazingly we have neglected it. It is hardly twenty years since Mr. Pinchot and the other pioneers began their work in this country; but in Germany, in France, in Switzerland, the care and culture of the forests have been a national concern for centuries. Their systems were thorough and elaborate before ours was begun. The German forests are valued at half a billion dollars. The French forests yield annually an average of two dollars the acre. Those of Switzerland are, if anything, even more carefully conserved and cultivated. With us, there was actually no law whatever providing for forest reservations until 1891 . In the matter of the national conservation of the use of water-power, we have in the example of Switzerland a still more admirable - a practically perfect - object-lesson. There is not a considerable waterfall in the Alps whose 


\section{THE NEW POLITICS}

force is not carefully calculated. Already a great part of the light and heat and power used by the Swiss people is supplied by Government from this source.

Concerning these things, therefore, there is hardly a question; but there is an issue; there is a conflict, a struggle; and the violence and magnitude and difficulty of it are greater than anywhere else in the world. That is so because nowhere else in the world are private interests so well organized or so powerful, and nowhere else have they had such opportunities to acquire control of the various means of wealth. There is thus an issue, more and more sharply defined, between the permanent public weal and the selfishness of individuals and groups. The mere wastefulness of the public itself, culpable as it has, of course, been, does not seriously threaten to turn into that spoliation by the people which Macaulay apprehended; but the accumulation of vast wealth by a few, which he also predicted, - that has come, and on a scale beyond his wildest dream. There has also come a massing together of both great and little accumulations, and an 


\section{THE NEW POLITICS}

organization of capital and industry under a few heads, which he apparently did not foresee at all, so that the struggle is not so much against the appetites and immediate desires of the mass of the people as it is a struggle on behalf of the people against the combinations. To take an instance which at once suggests itself, the lumber kings were not so slow as the rest of us to see how rapidly the country was being deforested. Mr. Pinchot did not need to take violent measures to arouse them to the situation. Mr. Pinchot, in fact, taught them nothing on the subject. They had already looked ahead, and were buying timber lands everywhere. Whether or not a similar concerted effort has been made to monopolize the country's water-power has been questioned; but it can hardly be questioned that, law and usage remaining what they are, the same forces which have made for monopoly and against competition in other things - in steel, in mineral oil, in anthracite coal, and the rest - will accomplish this huge monopoly as well.

The swift and universal rise of prices from which we now suffer will be really a blessing 


\section{THE NEW POLITICS}

if it shall serve to awaken us completely to the actual state of industry and exchange among us. Our awakening to the necessity of economy, of conservation, important as it is in itself, is still but a part of the greater awakening to the true extent of the changes that have come about in our industrial life; it is but a rubbing of the eyes to what we shall see when we are fully aroused. The field is so vast that only a superficial glance at the main features of the new order is here possible; but sometimes the swift eyesweep will yield enlightenment not to be won by a minute and piece-meal observation.

The most striking and important fact - a fact which is in a way inclusive of the whole matter - is this: Competition, as we have known it in the past, the kind of competition on whose existence and continuance our law and usage concerning industry and concerning property are largely based, is breaking down. From many industries it has already practically disappeared. Take any one of dozens of articles of general consumption, and thorough investigation will very likely disclose that real and vital competi- 


\section{THE NEW POLITICS}

tion no longer prevails in its production or in its transportation or in its wholesale or even its retail distribution. From whomsoever one buys it, one is really patronizing a trust or other combination. A combination of manufacturers makes it, a combination of common carriers fixes the charges for transporting it to the market, the original combination names the terms on which the retail dealers may handle it, - the main condition frequently being that they shall not handle competing products at all, - and the ultimate consumer is lucky if a combination of the dealers themselves does not fix the minimum price at which he can buy it. That such combinations of mere retailers exist in the great centers, and that there exists also the control or ownership of groups and chains of shops by the manufacturers themselves, has for some time been known. If our present investigations of prices go deep enough and far enough, I am sure they will also disclose such combinations in the smaller communities as well. The dependence of ordinary shopkeepers on the trusts or other combinations which supply their particular wares — such, for 


\section{THE NEW POLITICS}

instance, as that of the butchers on the meat trust - is so widespread that in this respect the old law of competition has been, in large measure, not merely nullified but reversed. Instead of individual manufacturers competing for sales to individual shopkeepers, who in turn compete among themselves for the consumers' favor, we have the shopkeepers compelled to restrict their business to the products of a group of manufacturers and taking their revenge by themselves combining against the consumer. The consumers, in fact, seem to be the only industrial group which has so far failed altogether to combine.

Illustrations are so abundant that one hesitates which to choose. Perhaps the tobacco business, since it was one of the first to yield to the principle of combination, will do as well as any other; but what is true of that business is true of so many others that it is necessary, in justice, to emphasize that it is taken merely as an illustration - that nothing invidious is meant by the choice.

The history of that business since the principle of combination, the trust principle, was first ap- 


\section{THE NEW POLITICS}

plied to it, exhibits plainly all the features of the new order which have been mentioned, except, possibly, the voluntary combination of the retail dealers in particular communities. There was first practically unlimited competition among the manufacturers, then the union of several companies in a corporation stronger than any of its rivals; then the sort of competition that never lasts, and which led simply to successive absorptions of all sorts of independent concerns by the original combination, the names of the various independent brands being, however, frequently retained; then the invasion by the trust of branches of the business in which it had not originally engaged; then - or perhaps sooner — the taking of measures for the control of the retail trade, such as the setting-up of chain stores and the practical compelling of retail dealers to handle only the trust's wares. Other means to overcome competition were doubtless employed, but these were the chief. And they have been so effective as to leave the consumer in large measure at the mercy of the combination. If he insists on buying a particular brand of tobacco formerly manufac- 


\section{THE NEW POLITICS}

tured by independents, he is very likely to find either that it is no longer manufactured at all or that it is now really manufactured by the trust - in which case the quality of the product has very probably been changed. Of course, some independent concerns are still doing business, and it is always possible to obtain their wares if the consumer prefers them and is willing to take the trouble to use the mails. The monopoly is not complete. But in respect of by far the greater part of the demand for tobacco in all its various forms, it has almost come to the point where the men in control of the bulk of the business can say to the consumer: "You can no longer choose for yourself what you will have. You must take what we supply."

Again let me repeat that I have mentioned this business merely as an illustration. Many other industries that would serve equally well as illustrations instantly come to mind. In fact, what does not come promptly to mind, what is getting harder and harder to find, is the industry, the business, of which what is true of this one is not either already true or plainly by way of becoming 


\section{THE NEW POLITICS}

true. One can scarcely pick up a paper without encountering the announcement that the same principle has been extended in some form to some new field. A combination of "general" stores in certain cities, and a practically nationwide combination of bakeries, are the freshest instances. It is impossible not to feel that the tendency is so universal as to mean unmistakably a new industrial order.

What does the change mean for the individual, not as consumer, not as in any sense a mere observer or outsider, for that can be the lot only of a number so small as to be negligible, but as a part and member, an industrial unit, of the new order, the new system? Clearly, it means, and it must continue to mean until the system is somewhat modified in the interest of the individual, less independence, a narrower range of opportunity. There is no reason to believe that it means, on the whole, less comfort or a lowered standard of living. The contrary is more probably true. The economies in most of the combinations doubtless outnumber and outweigh the losses, not from the point of view of the producers only, 


\section{THE NEW POLITICS}

but from that of the entire community as well. Neither does the change mean that the man of ability and ambition cannot rise. He can. A policy of promotions for merit is plainly to the interest of every great business. The great combinations have almost universally adopted that policy, and they follow it far more consistently than Government does. That is a principal reason why they are so well served. But that these things are so does not rid us of the fact that the coming of the new order has meant a real loss of independence, of industrial freedom, to the great mass of individuals. Their chance to rise is a chance to rise in but one way - by obedience to the laws of the systems to which they belong; and in the making of those laws they have had no voice. There is real independence only at the top; and to reach the top is beyond the hopes of any but a very, very few. In this respect the new order is, perhaps, more like the military system than anything else. Clearly, it is less democratic, less in accord with the democratic ideal, less conducive to the democratic spirit and temper, than the old. 


\section{THE NEW POLITICS}

But to get a fuller conception of the change, and how great it is, we must go higher. We must go to the source of initiative and control in business as it has come to be carried on in America; that is to say, to the men who direct the capital of the country. For the principle of combination has certainly not withheld itself from the sources of industrial energy any more than it has from particular industries. Of the announcements of mergers and combines which one sees so constantly, none are more significant than those concerning banks and trust companies in the great centers. To these there have also of late been added reports from the West of the formation of chains of banks in the smaller places, covering whole States or parts of two or three States - not the branch bank arrangement of England and Canada, but veritable bank trusts, controlling the main supply of capital for great regions. I suppose it was the insurance investigations of a few years ago that first revealed how it has been possible for a few great capitalists to get control of the accumulated savings of hundreds of thousands of people of small means. 


\section{THE NEW POLITICS}

Those investigations did not, however, lead to any comprehensive plan for arresting the process. It has not stopped, but gone on. According to a recent estimate, a single great banking concern is charged with the practical direction of some six billion dollars, variously invested — in manufactures, in banking, in transportation, in mines, in many other ways. To say that we already have a dominant, all-controlling money trust would be going too far. But it is not too much to say that the forces of the age make for such a consummation, that, our law and usage remaining as they are, that also is fairly sure to come about.

The possibility, taken with the vastness of our extent and our wealth, is staggering. Four centuries ago, the Medici were masters of Florence because they were supreme there in finance; but Florence at her best was but a city of perhaps one hundred thousand inhabitants, with a territory far smaller than that of our average single State. If, therefore, the Medici could make themselves so great a place in history, and play so great a part in the life of their time, what might not they do who should establish even a like control 


\section{THE NEW POLITICS}

over the limitless industry, the incalculable opulence, of America? In the presence of such power how could democracy survive? Such power could go far to corrupt the press. Less power has, in fact, already gone far to corrupt the press. Less power has already corrupted legislatures; has suborned executives; has reached even the courts. But these indirect and vile ways are not the only ways, perhaps not the most truly effective ways, in which such power would work to the undoing of democracy. When we shall have substituted the new order for the old régime of competition and free individual initiative in all the great industries, when every one of them shall be organized into a single system under a single-headed control, and there shall be set above them all the moneylenders, the financiers, themselves brought into an equal solidarity, we shall have gone far to deprive democracy of the very air which it must breathe to live. We shall have denied to the mass of individuals the use and practice of selfdependence, self-direction, the wont and exercise and habit of freedom, without which they cannot fit themselves either to win it or preserve it. 


\section{THE NEW POLITICS}

Here, I repeat, is but the merest glance at the new conditions; the merest flirting aside of the curtain. But it may, I think, be sufficient to enable us to formulate the chief of the new issues. We are confronted, let us say, with the problem of adapting the democratic principle to conditions that did not exist when our American democracy arose in the world: that is to say, to a field no longer unlimited, to opportunities no longer boundless, and to an industrial order in which competition is no longer the controlling principle, an industrial order which is, therefore, no longer democratic, but increasingly oligarchical, which may even become, in a way, monarchical, dynastic. To save itself politically, democracy must therefore become aggressively industrial; it must somehow extend itself into that field. Plainly, therefore, "laissez-faire" can no longer be its watchword. That was the watchword of the régime of competition. Democracy's task is twofold; it must secure for the State, the public, the people, some kind of effective, ultimate control over the natural sources of all wealth; and it must also secure, in an industrial system no longer 


\section{THE NEW POLITICS}

controlled by competition, protection and opportunity for the individual.

That twofold task and battle will not be easy. Democracy, in fact, has never faced a harder, a morecomplicated struggle. Ere she come through it victorious, she will have need to call upon the names of all her saints, to hearten herself with the memories of the deeds of all her heroes. For privilege, driven from the Church, hurled from the throne, has here in America made her seat and stronghold in the market-place, and fortified it with such a skill and energy as were never before spent in her service. We may hope that if it be taken it will prove her last. But we cannot feel that it will be easily taken; we cannot even hope to take it by the methods of our past fighting against oppression.

That ancient warfare must, in fact, be begun all over again, and with new tactics, new strategy. In the presence of the overshadowing new issue, many of the old issues will be altered, reshaped. The old struggle over the tariff will be less and less a mere matter of conflicting sectional issues, less and less a matter of contrary economic 


\section{THE NEW POLITICS}

theories, more and more a part and phase of the great struggle between democracy and privilege in industry. The old constitutional questions, many of which we have fondly thought forever settled, will reappear in new forms, and many new ones will also arise. Instead of being at the end of the period of great constitutional controversies, we are at the beginning of a new set of such controversies, deeper and more difficult than any that have come before. The rights and powers both of the States and the Nation must be scrutinized afresh. We shall be lucky, indeed, if we can stop with mere constitutional decisions and adaptations and changes. Before the end, we may well have to go back farther still, and find for the common law itself, if not new principles, at any rate, new formulas. For I doubt if we shall end before we have revised many of what we have thought our fundamental conceptions of property and of human rights.

I doubt, indeed, if democracy alone is in danger, if democracy alone is the sole matter of the argument, the true stake of the contest. They that enlist in the new war, though they begin as de- 


\section{THE NEW POLITICS}

fenders of democracy only, may find before the end that they are in truth fighting in a still holier cause and can take their inspiration from a still greater name. Liberty, to save herself and all her immemorial winnings, must come herself into the field. And she cannot come as when, in the past, she has come to lift up peoples abased by kingly or aristocratic oppression or crushed by armies or yoked with the yoke of priestly bigotry. Coming now to lift up a people bowed down before the face of wealth, she must take on a new aspect, cry new invocations, learn new ways of warfare. She must get new weapons and a new armor. It may even be that she must wear a new face and form, and find for herself some other beauty than that with which, for so many ages, she has won to her hard service the noblest of mankind. 


\section{THE NEW POLITICS}

\section{PARTIES AND MEN}

None of us are entirely content with our political parties as they are. A good many of us hardly ever mention them except to abuse them. But only one prominent American, Mr. W. R. Hearst, has of late years made any persistent effort to get rid of the old ones and substitute new; and he does not seem to have had any great success. No one has seriously proposed that we try to get on without any parties whatsoever. Parties of some sort are the only device we have for making our Government work. We can deal with the issues presented by the new politics only through parties; through the old ones if they do not divide too hopelessly when they come to face those issues; through new ones if they do. In any case, however, we shall at least begin with the old parties.

I will repeat the statement I have made of what seems to me the present task of democracy in America, the problem presented by the new 


\section{THE NEW POLITICS}

order which has come about in industry and business almost simultaneously with the final coming of the Republic into a sense of the limitations of its material resources. The present task and problem of democracy is twofold: to secure for the State, the people, some effective ultimate control over the natural sources of all wealth; and to secure, in an industrial system no longer controlled by competition, protection and opportunity for the individual.

The contest now forced upon us is, of course, but another form or phase of the immemorial struggle with privilege. But the phase of that struggle upon which we are now entering may, I think, be not unreasonably considered the most important, the most crucial of all. And for this reason: The kind of privilege with which we must now join battle is the product, not of monarchy or aristocracy or priestcraft, but of democracy itself. It has grown up out of a free soil. The new organization of industry into great combinations, which has gone so far toward crushing out competition, began itself in the freest competition; it was in fact accomolished through the 


\section{THE NEW POLITICS}

methods of competition. First competition, then absorption - that has been the process. But for the freedom which our laws and usage allowed, - the free play they gave to all kinds of ability, the opportunity they opened to all kinds of talent, - it is doubtful if these tremendous aggregations of energy and wealth and system could have been built up so swiftly. Certainly, no country where the older forms of privilege prevail has ever matched them. Being, therefore, products of a society established in opposition to the entire conception of privilege, they may seem to prove that there is something in the very nature of great human societies which makes for privilege - that there is something, perhaps, in human nature that makes for it. But whatever the fundamental trouble, the root of the evil, may be, it is not entirely unreasonable to hope that this time, since we are dealing with a kind of privilege native to democracy itself, we may eventually get at it. What I mean is that we may eventually find our struggle turning into a warfare with the very life principle of privilege; that it may, therefore, prove to be the final war - the last of the long series that 


\section{THE NEW POLITICS}

began either with the first raising-up of the head of authority in some pristine democracy or else with the first glimpse of the face of freedom in some original despotism.

That, of course, is a long, long hope; and these are large and bold conceptions. To pass from them to a study of our Democratic and Republican parties of to-day is rather an anticlimax - like turning from Burke or Milton to the newspapers. But I know no other way to be practical.

The tendency in all self-governing or partly selfgoverning societies is to have at least one party which is distinctly, at any rate habitually, the party of privilege and at least one party which is habitually opposed to privilege. There may be other parties, advocating special causes. One or the other of the two great parties may from time to time split and divide on particular issues. They may both from time to time fall into inconsistencies, failing to adhere to their essential motives and life principles. All sorts of departures and variations occur. But this remains the normal division and alignment. One may prefer, with Mr. Bryce, to call one party the party of order and 


\section{THE NEW POLITICS}

authority and the other the party of progress. But the choice of words is not particularly important. The general character of the division is fairly well indicated by either set of terms.

I have elsewhere ventured to argue that $\mathrm{Mr}$. Bryce and De Tocqueville, and other foreign observers as well, have erred in denying that the two great American parties have stood, on the whole, for this normal party division, and I still hold that opinion. But I admit freely that none of our parties has stuck steadfastly to its proper rôle. Apart from the forces that ordinarily make against consistency in politics, the federal form of our Government has been the cause of a long series of divisions - divisions over the powers of the States and of the Nation - that have often obscured the more universal division. Now and then these old questions - questions of state rights and federal powers - reappear. But they have lost their heat. They have lost much of their interest. There is something academic about all the present-day discussions of them. I think it is clear that they now play a far less important part than they used to play in our politics, and have much less effect 


\section{THE NEW POLITICS}

than formerly on our party divisions. These may, therefore, be expected to follow hereafter more closely than they have hitherto followed the general usage of parties in representative governments. One will stand rather more distinctly than formerly for order, authority, system, effectiveness; and that will be the party through which privilege will most naturally seek protection and extension. The other will rather more distinctly than formerly stand for democratic aspiration, for the rights and the hopes of the individual, for equality of opportunity; and that will be the party which on the whole will offer the most antagonism to privilege.

But of the two great parties now in existence, which will be which?

Until quite recently, I do not think many of us would have hesitated on this point. Although the Republican party began as the party of freedom, of manhood rights, and in opposition to one of the worst forms of privilege that ever existed, the institution of slavery, I think most of us would have said that in its later history it has been pretty distinctly the party of order and authority in this 


\section{THE NEW POLITICS}

country, and therefore the party to which privilege would most naturally look for favor and protection. It has had that character for several reasons. It has had a majority of the wealthy in its ranks, and it has naturally been more responsive to their views than its rival. It is the party to which people who have had, as the saying is, a stake in the country have naturally gravitated; and one potent reason for their coming into it has been its long ascendancy, the long lease of power which the country granted it after the Civil War. It has had control of the Government. Strong, successful, practical men have turned to it because it could do things, and men of that character have become its ruling spirits. Great interests of all kinds have attached themselves to it. As it gradually committed itself to the policy of protection, those who profited or hoped to profit by that policy became inseparably attached to it. As the issues which it was formed to meet disappeared, its character changed. It became more and more the champion of the great interests which filled its campaign chest and demanded in return the legislation they wanted. A more thoroughly business-like 


\section{THE NEW POLITICS}

party never existed. It has for decades commanded the best practical ability in the country. As our industrial system altered, when first the great corporations were formed, and then the trusts, until from many fields competition disappeared, nothing was more natural than that the men at the head of the great combinations should find this party sympathetic. They were the same kind of men, not infrequently they were the same men, who were already dominant in its councils. Both from its composition and from its association with great business interests, the Republican party was apparently certain to become the political representative of the new order; the representative of power; the representative of wealth ; the representative of combination as opposed to competition, of coöperation and coördination and system as opposed to individualism; the party, therefore, of privilege - of the new kind of privilege.

Certainly, its rival was not well fitted for that rôle. The Democratic party had, it is true, at a certain time in its history, stood for a great special interest. The long lease of power which it enjoyed before the Civil IVar had the usual effect 


\section{THE NEW POLITICS}

of power on a party of liberal principles. It grew more complacent with things it had come into existence to oppose and less fiery for the ideas it had come into existence to advance. It became more complacent with authority, less fiery for liberty. The genuinely democratic impulse which it had received in Jefferson's time and again in Jackson's had no renewal under Polk and Pierce and Buchanan. While it was in this state the slavery issue came to dominate all others; and both the old parties divided over it. The Whig party went to pieces. Among the Democrats, the Southern or pro-slavery faction got the upper hand and kept it until the disruption of I 860 . Unfortunately, two truly democratic principles, the principle of individual liberty and the principle of local selfgovernment, both thoroughly sound within reasonable limits, had been brought, by the anomalous fact of slavery in a republic, into a kind of conflict. The distracted party held to the principle of local freedom, of state rights, and abandoned the principle of individual liberty, of the rights of man. The slavery interest, the very greatest single interest in the country, for a time controlled it. For a 


\section{THE NEW POLITICS}

time, therefore, it may be said to have been the party of the established order, the party of privilege.

But for the last half-century the Democratic party has had very little of the power that corrupts and demoralizes. Neither has it had the kind of membership that would make it complacent with privilege, nor yet have the great material interests attached themselves to it. It has, indeed, from time to time won as recruits independent men of wealth; but its principal gains have been among the working-people of the great cities, particularly among the foreign-born and among the plain farmers of the West. The old slaveholding interest of the South has, of course, disappeared, and the large Southern membership of the party has had, since the war, an influence on its policy very different from that which the slave interest exercised before the war. For theSouth has been poor; it has been relatively weak; it has felt itself on the defensive; on the outside of things and not on the inside. In the South, moreover, the plain man, the man with neither wealth nor distinction of birth, has been steadily coming to the front. The old 


\section{THE NEW POLITICS}

Southern aristocracy has lost its political ascendancy, and the new industrial oligarchy has been slower to develop there than elsewhere. The voice of the South in that party has accordingly been, since the war, the race issue alone apart, decidedly against any kind of condoning of privilege.

On the whole, therefore, I think we may say that as the new issues began to force themselves upon the country, as the great changes in our industrial system came about, and the new kind of privilege began to make itself felt and understood, it was decidedly the Democratic party to which one had best reason to look for opposition to that new kind of privilege. That was the party which seemed, on the whole, to have decidedly the best right to claim support as the party of individual liberty, of democracy in the full meaning of the word.

And that, I think, has been its real bent. For the past ten years its specific proposals have been, for the most part, unfortunate. It has suffered also from bad management, from bad organization, from factional divisions. It has suffered from 


\section{THE NEW POLITICS}

lack of intelligence. As contrasted with the business-like control and direction of the Republican organization, its leadership has been pitiably weak. The party has been distrusted, and the people have refused to grant it power, because they have felt it to be incoherent, unbusiness-like, ineffective, more like a mob than an army - but not because it has not been democratic in animus and temper and composition. For years, in fact, it has wanted only able and intelligent leadership and firm organization to commend it to popular favor. A majority of the American electorate would many times have preferred to support that party if they had not been afraid to.

Such, then, was the general state of both parties when the new aspect of industry and finance forced itself upon the attention of the people in a way to demand a distinctly political attention. Then two things happened which have profoundly altered the party situation. One was Mr. Roosevelt's promulgation of what have come to be called the Roosevelt policies. The other was the Progressive or Insurgent movement in the Republican party. 


\section{THE NEW POLITICS}

The two things were certainly not unrelated. Which began first will doubtless in the future be discussed by historians, but to determine whether ex-President Roosevelt really got his cue from the Western Progressives or they got theirs from him is not of the first importance. Both he and they had come to feel that to retain the confidence of the country their party must somehow counteract the impression, already widespread, that it was subservient to great private and corporate interests; that it must, therefore, strike out on a new line and consider more candidly the changed conditions of industry. Both he and they had vision enough to see that there was growing up and becoming powerful in this country a kind of discontent somewhat different from that which has produced most of the revolutions and political overturns of the past; a discontent not so much with actual as with relative material conditions, not so much with actual suffering or poverty as with inequalities, and particularly inequalities of opportunity.

The fact and the volume of that discontent in America is a striking and a creditable thing. Many 


\section{THE NEW POLITICS}

of our people who are most dissatisfied are living fairly comfortable lives. They do not lack bread or shelter. They have work, and their earnings seem, as compared with the earnings of the same kinds of labor in other countries, decidedly high. But they see other men enjoying not merely greater wealth, but a kind of power which they themselves cannot hope to attain. They perceive that they are mere parts of systems, the control of which has passed to a few men; that these systems are growing constantly bigger and absorbing more and more of the industrial energy of the country; that it is, therefore, no longer reasonable, as it once was, for every man of character and intelligence and energy to hope to make himself the independent master of his own business, whatever it may be. Instead of that, they find all the main industries, including the various forms of commerce, tending to combination and consolidation, with a very small group in control, and the workers of all but the highest grade or rank deprived completely of initiative, and indeed reduced to be mere parts of a great machine, valueless and powerless if detached. Of course this 


\section{THE NEW POLITICS}

change has caused some actual hardship. But the discontent with it has been something more than a mere clamor for a bigger share of the good things of life. The democratic instinct, the instinct and principle of individualism, of independence, of human rights, has been at the bottom of it. That instinct has taken alarm, and the alarm has spread through both the parties. The reason why this feeling has had more striking and visible effects in the Republican party than in the opposition has been that it had more to overcome in that party than in the opposition.

Whether we give the credit for originality in this matter, for first perceiving the coming on of a new democratic impulse, to ex-President Roosevelt or to the Western Progressives, whether we consider that he acted as patriot and leader and prophet or only as an astute politician, there can be no denying that his political instinct was keen and correct. But ex-President Roosevelt, when he went out of office, had merely announced a general policy concerning the combinations and had done little more than that concerning the conservation of our resources. And even in his very 


\section{THE NEW POLITICS}

general announcements of policy he on one point either differed from the Western Progressives or at least failed to go their lengths. He made no attack on the system of high protective tariffs. $\mathrm{He}$ failed, therefore, to strike at all at that particular bond between his party and the great interests which many have regarded as the least defensible of all. The Western Progressives did strike at it, and it was that part of their programme which, as we all know, brought them first into open conflict with the conservative wing of their party.

That conflict has now widened and deepened into a positive breach or schism which cuts through the party everywhere except, perhaps, in the South. The division has, for the time being, altered the face of American politics, and it has upset all calculations and forecasts.

To attempt a forecast even of the course of the schism itself would be venturesome. But either the Progressives or the Conservatives will win, let us say, in their present fight for control inside the lines of the party lines. If the Progressives win, the party will be profoundly changed. But in that case the chances are at least even that the Conserv- 


\section{THE NEW POLITICS}

atives will not withdraw; they may feel that they have no other place to go; and if they remain in the party their presence will be enough to keep it from becoming radical - to keep it from becoming more than moderately liberal. If, however, the Conservatives win, the Progressives are not so likely to acquiesce and remain loyal. On the contrary, there is a very strong probability that they will secede; that they will either attempt a new movement and organization of their own or join with the present opposition or some part of it. It is a question, therefore, whether they or the present Democratic opposition will be the true liberal party of the future; but to that liberal party of the future, whatever form and name it may take, both the Progressive Republicans and the present opposition will contribute of their membership; and, on the other hand, we may be sure that wherever, in the new alignment, the Conservative Republicans, the so-called "Standpatters," the men who for some decades have been the real rulers of this country - that wherever these shall find themselves, there will be the party of authority and order, the party of the new kind 


\section{THE NEW POLITICS}

of privilege. To them will doubtless be joined many conservative men, Tories in temperament or by conviction or from the character of their personal interests, who now call themselves Democrats. The composition of the two parties of the future seems in fact fairly easy to predict.

But whether they will be two new parties, with new names, or merely the two old parties materially changed in composition and much more sharply differentiated in policy than they now are - that depends on the character and the effectiveness of the leadership of the immediate future. A leader of the Republican Progressives comparable to Hamilton or Jefferson or Lincoln could in all probability make of them a true and complete party, so strong that a great part of the opposition would in the long run be drawn into its ranks. The rise of such a man among the Democrats would, on the other hand, probably have a precisely contrary effect.

There are people, many people, who feel that the Republican Progressives already have such a man. There are also people, though not so many, who would contend that the opposition has such 


\section{THE NEW POLITICS}

a man; and the claims of this sort that are made for Bryan are as sincere as those that are made for Roosevelt. But they are not at present taken so seriously. It is said that Mr. Bryan has been for years proclaiming the issues and advancing the ideas which are now transforming our politics; that he was in this respect far in advance of Roosevelt. This is measurably true. There are demands in the Progressive programme, there are "planks" in Roosevelt's Ossawatomie "platform," which were urged by Mr. Bryan before the terms "Progressive" and "Insurgent" came into use, before Roosevelt became President and announced his policies. But along with these things $\mathrm{Mr}$. Bryan has put forth other ideas, other proposals, which have been utterly and deservedly rejected; and he has supported them with a kind of reasoning which many of us find not merely shallow and unconvincing, but culpably sophistical. Whatever sincerities and whatever soundness there may be in him, a great body of thoughtful and sober-minded Americans, many of them members of his own party, are fixed in the conviction not merely that he is an untrained mind, a mind lacking in judg- 


\section{THE NEW POLITICS}

ment as well as training, but that he is too unstable to be trusted with power. It is hardly conceivable that his prestige and his hold on public opinion will ever be greater than they have been. They are now less than they have been; and they seem likely to continue to diminish.

With Roosevelt it is different - very different. He still fills the public eye as no other man of the time has done. Apparently, his going out of office has not lessened at all the interest in his personality and his career or at all narrowed his extraordinary access to public opinion. It is many years since any American has had so great a fame as his or such obvious and widespread influence. Every public utterance he makes reaches the entire country. He can have an instant hearing for any proposal, any contention, he cares to put before the Republic. Moreover, he plainly desires to continue to lead. He seeks to put himself at the head of the Progressive Republicans; and all the signs are that the majority of the Progressive Republicans wish him for their leader. When, therefore, it is asked, why he is not the man of the hour, the man of the age, the man providentially raised up to be the 


\section{THE NEW POLITICS}

captain of all the forces of democracy in the warfare against the new kind of privilege, a convincing answer does not at once frame itself.

He will not fail to play that rôle from any lack of energy or of shrewdness or of the instinct for affairs - the instinct of leadership. No more skillful politician, in the full and not invidious sense of that much-abused word, has ever lived in this Republic, if in any republic. It is by no means preposterous to compare him with either Cæsar or Napoleon if one has in mind only their civil and not their military characters and careers. Neither in revolutionary France nor in the overgrown and decadent Roman Republic could such a man have been kept down. His detractors merely hurt their case when they refuse to acknowledge the uncommon force there is in him. In face of his actual performance in self-advancement, it is difficult to doubt that he possesses "the thews that throw the world." Perhaps it is true that he has no particular gift or power which can properly be called genius; that he has won his battles solely by an extraordinary use and development of gifts not extraordinary in themselves. But 


\section{THE NEW POLITICS}

that does not leave him any the less extraordinary in the actual effect. Such will and energy are themselves as rare as genius - and far surer to prevail. It is they, in truth, that make the conqueror as we know him in history; and that is plainly the type to which Roosevelt belongs. His sleepless ambition and ever-growing egoism are entirely in keeping with it. The frail body disciplined to robust strength and hardihood, the student and idealist turned into the ultra-practical man of affairs, the halting speaker and writer become a monopolist of public utterance, the appetite for action and for power, once aroused, growing ever with what it feeds on, until it is become insatiable what is all this but the normal course and development of the character that all through history has belonged to the setters-up of dynasties, the regenerators or overthrowers of kingdoms, the founders or the subverters of republics?

Fairness will concede extraordinary attraction as well as extraordinary force. There have been admirable, even noble, impulses, the gift of comradeship; zest in human relationships, and love of nature, and joy in life; integrity in private deal- 


\section{THE NEW POLITICS}

ings, and continence, and domestic virtues. There has been, of course, courage always, and an inspiring sense of opportunity and of the range and possibilities of life. There has been a ceaseless intellectual activity, never, it is true, particularly fine or original, but keen and quick and wide of reach, playing over the entire field of human interests. It is a personality that can win as well as overcome.

Yet I cannot feel, and I do not believe that many dispassionate and painstaking observers of this career can feel, that here is the right leader of our American democracy in its present crisis. Many, on the contrary, are coming to feel that in precisely such a man there may be more immediate danger to the American democratic ideal than even in those new industrial forces against which his leadership is invoked. It is becoming a commonplace that those forces and our present industrial conditions were not contemplated when our system was founded; that the fathers did not foresee them and could not, therefore, set up safeguards against them. But the fathers were not without forethought of the danger of the coming of such a man as is now risen up among us - a man too popular, 


\section{THE NEW POLITICS}

too powerful, and too ambitious. It is clear from their debates that they had in mind both the misadventures and the preventive usage of the ancient and mediæval republics, in every one of which there dwelt a constant terror of the man too long in power and in the public eye, the man with too great a following, the man too preeminent above his fellows. It was of the essence of the spirit of the ancient republics, as it was of the spirit of republican Florence, not to expect to find the virtue and forbearance of their great men equal to their strength, and to refuse, therefore, to risk the safety of the State upon the doubtful hazard of the conflict of ambition and patriotism in any human breast. Our own founders limited the term for which a President could be elected to four years, and they also undoubtedly intended the device of an electoral college to operate as a check upon popular impulse. That device failed. But when Washington retired at the end of his second term his example was quickly seized upon and converted into a precedent - a precedent which has hitherto proved strong enough to keep any of his successors from serving longer than he did. 


\section{THE NEW POLITICS}

That precedent has undoubtedly had great weight with the electorate, but it has also had the effect of an admonition and an appeal to Washington's successors themselves; and to not one of these has it ever appealed so logically as it does today to Theodore Roosevelt. All that I have said and all that can be said, in praise of his character and his achievement, merely makes it so much the more applicable to his case. For the kind of danger contemplated in the apprehension which has made that precedent so effective could not come from a weak man, but only from a strong man; it could not come from an unpopular man or a man generally distrusted, but only from a man grown too popular, a man trusted too widely and too slavishly. Of course, too, the man to be feared must be ambitious, and that Roosevelt has from first to last been keenly ambitious even his admirers do not deny. He has proved himself not merely ambitious, but of an imperious and arrogant impatience with whatever hinders or stays him, whether it comes from men or from laws. With men he has again and again displayed, now a tyrannous and coarse violence, now an indirec- 


\section{THE NEW POLITICS}

tion and sharp practice, which simply cannot be condoned. However one considers such things as his dealings with Quay and Platt and Harriman, or his brutal fury with his critics of the press and with Judge Parker and other political rivals, or his entire behavior concerning campaign contributions in 1904, or the bullying and unfairness with which he has repeatedly met opposition, one's republican instincts and one's instincts as a gentleman are equally outraged. With laws he has been even more high-handed than with men. From first to last he has been egregiously lacking in that scrupulous and reverent sense of law, of precedents, of institutions, which has been hitherto the rule of both American and English statesmanship, and none of his public utterances shows the lack of that sense more glaringly than his recent setting forth of the "New Nationalism." Of all his predecessors in the White House only Andrew Jackson can be compared to him in this respect. And Jackson, demoralizing as his "reign" was, never was half so really dangerous. For Jackson had no such consuming ambition, no such sweeping designs of change; and when he came into 


\section{THE NEW POLITICS}

national power he was already elderly and infirm. Should Roosevelt again take the first place in the Republic, no one would expect to see him conduct himself as an ordinary President in time of peace. His power would be greater than Jackson's at its height; and there is every reason to believe and none to doubt that he would wield it with a worse than Jacksonian disregard of legal and constitutional limitations.

One may have the firmest faith in our system and still shrink from submitting it to such a strain. No doubt, Lord Morley's observation in " Compromise" is sound: a reasonably healthy state has immense strength; it has abundant reserves of vitality to throw off disease and recover from shocks and confusions and derangements of its order. But every departure from its right order, every lapse from its essential principles, leaves it more open to the next. I do not believe that Roosevelt, I do not believe that Napoleon or Cæsar, could in a day or a generation subvert the institutions of this country; but not for that reason ought a Napoleon or a Cæesar to be welcomed; and not for that reason should any intelligent Ameri- 


\section{THE NEW POLITICS}

can disregard the danger that there is in Roosevelt.

Clearly, unmistakably, the precedent we have made from Washington's example is apposite, applicable. The warning of it comes home. It warns us against him. But may we not hope that also, since he also is an American, since we need not believe that he does not really love his country, it will in time, and potently, warn him against himself? That he will yet, and in time, take to heart some of the words forever on his lips, and read aright the lives he has so often commended to us - Timoleon's, Hampden's, Washington's, Lincoln's? That he will learn at last the supreme nobleness, rise to the supreme opportunity, of self-abnegation? That the ideals of youth will yet revive in him and conquer the coarser impulses of manhood? That he will yet, and in time, -

"Curb the liberal hand, subservient proudly" ?

By no conceivable self-assertion could he now render to his country such a service as it is open to him to render by crucifying his own ambition; and in no other way could he make his own fame 


\section{THE NEW POLITICS}

so secure. Nor would the act cut him off from such service, such leadership, as would in truth be most truly valuable to the country and most honorable to him. Let him once pledge himself in plain words never again to seek or to take the presidency, and his power to advance causes, his hold on public opinion, his opportunity to contribute what he has to contribute to the solution of the new problems, would not be less, but greater. If, however, he will not do that, his leadership, so far from helping us with our new perplexities, will merely complicate them with the old problem and danger which from time to time has beset every experiment in republican governmentthe problem and danger of "the man on horseback."

We shall proceed better, because more safely, more in accord with the spirit of our own and the English law and usage and institutions, with less risk of either destroying what we have or establishing what we shall have to destroy, if we go on without recourse to anything at all in the nature of a dictatorship. Our emergency is not of the character that demands such a remedy; nor could 


\section{THE NEW POLITICS}

such a remedy work us any lasting good. Our need is of a permanent adjustment to conditions likely to endure; of laws thoroughly considered and carefully framed; of deep-reaching changes in our social habit and usage - such changes as can only be brought about slowly, with a wise patience. For work like that such a temper as Roosevelt's would be almost the worst conceivable. That of his successor, though less inspiring, is far better. But it is doubtful if any one man's leadership will bring us far upon our road. For the long and hard enterprise now before democracy in this country the best abilities of many men will be needed, and those abilities will need the best training to be got from schools and colleges and from life and experience. There must be an extraordinary coöperation, a difficult and unprecedented bending of countless energies, in many fields, to the same general and impersonal ends. Ordinary popular leadership will not suffice; from the one-man power in whatever form, from masterful and swift determinations of whatever kind, we have little to hope. American politics are become a hard occupation. The Republic 


\section{THE NEW POLITICS}

has never before demanded a more serious and patient attention to its affairs, or from so many men. For, whatever the changes that shall in the end make our system valid and firm against the new conditions, they must extend through the whole of it, in all its federal vastness. The test to which our public opinion and our great electorate are thus submitted is no less than this: that there must be a widespread, an intelligent, and a stubborn patriotism.

The demand of the Republic for many men who shall be not merely patriotic, but of a high intelligence and highly trained, who shall combine common honesty with shrewdness and insight, is indeed severe. And for the difficult service demanded the reward may not be high. It may well be martyrdom instead of gratitude; to be misunderstood rather than to be honored; to be used and then cast aside.

But the immemorial promptings to nobleness abide. It is, after all, service and not self-seeking which oftenest in the end prevails. Though many men who seek only their own advancement or their own profit in this country's affairs win to 


\section{THE NEW POLITICS}

their goals and have their low desire, they and their works pass swiftly.

"In the unscarred heaven they leave no wake."

They who, on the other hand, give themselves sincerely to the common service - and they, too, are many, for it is not for nothing that we have been so long a free people in a favored land - will find that what they have wrought will stand; that it has been as if some gracious and tutelary power guided their hands to noble and enduring workmanship. They will find - as good men always find in the end - that they have builded better than they knew.

1910. 
PROPHETIC VOICES ABOUT AMERICA 


\section{PROPHETIC VOICES ABOUT AMERICA}

$7 \mathrm{HE}$ tone and spirit of American writing about 1 America is much better than it used to be. As our foreign critics have ceased to be supercilious, we ourselves, it would seem, have ceased to be vainglorious. Here beside me are some half-dozen volumes of essays, lectures, and studies, all by Americans, all about the Republic, all fresh from the press.' In not one of them does the Eagle scream. Not one of the writers even claims that our great experiment of democracy is yet proved successful. None of them, it is true, are really pessimistic. A note of discouragement here and there is the worst one finds. But all acknowledge frankly the disappointments in our past, all face candidly

1 Yale Lectures on the " Responsibilities of Citizenship": Tbe Citizen's Part in Government, by Elihu Root; Four Aspects of Civic Duty, by William Howard Taft; True and False Democracy, by Nicholas Murray Butler; Standards of Public Morality, by Arthur Twining Hadley; American Legislatures and Legislative Metbods, by Paul S. Reinsch; The Spirit of the American Government, by J. Allen Smith; The Industrial Republic: a Study of the America of Ten Vears Hence, by Upton Sinclair. 


\section{PROPHETIC VOICES ABOUT AMERICA}

the perplexities of our present; only one claims with confidence to have penetrated the clouds that shut out the future.

The writers are for the most part men entitled to a respectful attention. One is of the small group from which, in all human probability, we shall choose the next President. Another, his colleague in the Cabinet, many of us would pronounce the best mind in the Government, if not in our entire public life. Of the two, Secretary Root shows, I think, much the better literary instinct. Considered merely as serious prose about great topics, his addresses invite comparison with the writings of English rather than American public men, of whom so very few make a good appearance in print. Now and then, there is a kind of quiet depth of meaning in his sentences that actually reminds one a little of Lincoln. Secretary Taft has not such a gift; but he achieves a detachment, an air of thoughtful, disinterested concern about public affairs, as of an honest, well-bred gentleman, which one too often misses in the utterances of even our highest public officials.

Two presidents and two professors of universi- 


\section{PROPHETIC VOICES ABOUT AMERICA}

ties maintain the usual large proportion of academic contribution to this as to all other topics about which books can be written. As it happens, both Secretary Taft and Secretary Root have taken occasion to point out the limitations of the academic point of view concerning affairs. According to the former, it has too great "certainty and severity"; and Secretary Root, while setting the highest value on the public schools as opening the door to opportunity and service, admits a doubt "whether the higher academic education contributes much to capacity for political usefulness." But the presidents of our greater unversities become perforce men of affairs, however academic their ideals and training may be. President Butler seems in far greater danger of error from oratorical fervor and rhetorical facility than from any timid preciseness of scholarship. President Hadley has more of the academic quality in his style, and what may be a bit of New England acerbity as well; but his point of view is almost irreverently practical, common-sense, contemporaneous. And even to the mere professor, the mere scholar, however we may bow and smile him out of court when 


\section{PROPHETIC VOICES ABOUT AMERICA}

he begins to philosophize, we must concede a certain competency for investigations of facts, such as Professor Reinsch has made in his study of American legislatures, and such as constitutes the main part of Professor Smith's study of the Constitution.

The last writer of our group, Mr. Upton Sinclair, is a socialist; he is also, it must be confessed, a decidedly sensational novelist. But in the company of two statesmen and four academic dignitaries we may venture, perhaps, to let him also say his say.

It is but just, indeed, that he or some other socialist should have a word; for hardly one of the others is content to leave socialism entirely alone. So much, at least, the socialist propaganda has accomplished; conservative publicists, however they may reprobate it, do not treat it as negligible. Nor is their reprobation so strongly tinctured as it once was with contempt. Secretary Taft is, it is true, contemptuous of the mere "parlor socialist," for whom, in fact, he reserves his most scornful word; but he will not deny sympathy to the socialistic impulse of men who have really suffered under our present economic arrangements. President 


\section{PROPHETIC VOICES ABOUT AMERICA}

Butler concedes to the propaganda both sincerity and ability, and is content with the refutation, effective perhaps, but rather worn, that socialism is an illogical attempt "to overcome man's individual imperfections by adding them together." Secretary Root ends a remarkable sentence, descriptive of the dangers which beset on either side the true course of popular government, by contrasting " the dreams of Utopia, to be realized by changing every thing," with " the reverence for the past that is horrified by changing anything" ; and later on, summing up the grounds of hopefulness, he takes comfort in the diminishing proportion of avowed socialists in the American labor unions.

On the whole, what is most striking in nearly all these animadversions on the Republic is the entirely serious way in which the writers address themselves, not perhaps to socialism itself, but to that aspect of American life which is most provocative of socialistic remonstrance. Were a socialist to read them all together, as I have done, he might well be tempted to quote them Kipling :-

"Nor call too loud on Freedom, To cloak your weariness." 


\section{PROPHETIC VOICES ABOUT AMERICA}

For all have much to say of liberty. But it is a far cry from the kind of defense of liberty which they offer to the old defiances of kings and aristocracies with which we Americans began. Here is not a word, in fact, concerning tyranny of the oldfashioned sort. On the contrary, here is more than one vigorous assertion of the utter distinction, the contrast and incompatibility, indeed, between liberty and equality. Secretary Root's declaration has been celebrated journalistically as extraordinary and as courageous. "After many years of struggle for the right of equality," he remarks, "there is some reason to think that mankind is now entering upon a struggle for the right of inequality." The phrasing is uncommonly good, but the contention is far from extraordinary: the commitment would hardly seem bold if the speaker were not a public man and an officeholder. On the contrary, this is the main thesis of President Butler in more than one of his papers, and he keeps iterating it as if he were discontent because he cannot find words violent enough to arouse us all to its axiomatic truth and its vital importance. Clearness on this point, he 
urges, is the essential distinction between a true and a false conception of democracy. "We must put behind us the fundamental fallacy that equality is demanded by justice. The contrary is the case. Justice demands inequality as a condition of liberty and as a means of rewarding each according to his merits and deserts." And again: "The corner-stone of democracy is natural inequality, its ideal the selection of the most fit."

The thought tempts to epigrammatic overemphasis in the statement; and no doubt we Americans have often fallen into a slipshod neglect of such distinctions among ideals which, not long ago, we were disposed to consider peculiarly our own. To emphasize this particular distinction, even to over-emphasize it, may be a good way to get rid of whatever there may still be left in us of the old hazy bigotry. But are we not again befooling ourselves if we fancy the distinction a discovery, or if we try to make it broader and harder and faster than in truth it is? President Butler, for instance, takes too little pains to point out that the equality he is contemning is equality of economic condition, not of privilege. He does not 


\section{PROPHETIC VOICES ABOUT AMERICA}

pause long enough to consider fully the claim that the denial of equality of industrial opportunity may utterly defeat that very ideal of liberty which he holds up to us as the essential and the summum bonum of democracy. On this point, his oratorical approach to the problem leaves him - and even Secretary Root may be a little open to the same criticism-decidedly at a disadvantage as compared with the least distinguished of our group.

Professor Smith's deliberate account of the founding of our government, mainly a searchingout of the old intrenchments of privilege in the Constitution, has led him on to a more careful qualification of his statements. The American doctrine of liberty, he points out, had its origin in economic conditions quite unlike those of to-day. It was in fact based on the assumption of equality of economic opportunity; and under the old industrial system of apprenticeship and private initiative, before the days of machinery and corporations, a practical equality of opportunity did in fact exist. If, therefore, as socialists claim, and as we all know to be in great measure true, the coming-in of machinery and the concentration 


\section{PROPHETIC VOICES ABOUT AMERICA}

of capital in a few hands have destroyed equality of industrial opportunity, the principle of liberty would seem to be in need of a new application.

And Professor Smith thus works his way to what seems the most valuable generalization I have found in any of these writers. When the masses were economically independent and substantially equal, he argues, the aristocracy, the powerful few, - dominant politically in America as everywhere else at the time of our beginnings, - could maintain their place and power only by keeping hold of political privilege and making the State all-powerful. The doctrine of "laissez faire" was, accordingly, the right creed of the masses at that time, - the time, that is to say, of Rousseau and Adam Smith and Thomas Jefferson. They did not need the help of the State to protect themselves economically; on the contrary, they had good reason to fear that the State, considered as a merely political machine, over which they had little control, might be used by the aristocracy to deprive them of their economic independence. To-day, the situation is reversed. With the gradual attainment of universal suffrage the 


\section{PROPHETIC VOICES ABOUT AMERICA}

people have got control of the State; but meanwhile they have been losing control of the means and appliances of industry, they have been losing their economic independence. The parties to the old controversy have accordingly changed sides. It is the wealthy and privileged few who now cry, "Laissez faire!" It is the unprivileged many who desire more and more governmental interference with industry. What was once the radical platform is become the conservative, and what was once the conservative is become the radical.

It is a generalization which I think many sincerely liberal minds, opposed to privilege, but confirmed in the habit of associating privilege with the entire theory of a strong and paternal government, may come to welcome. It is firmer ground, one feels, than the footing of Secretary Taft when, before an audience of Yale undergraduates, he tries to explain how experience has modified the rigidity of the laissez-faire notions which he imbibed when he himself was a Yale undergraduate and his father a member of the Cabinet. "I think these principles," the Secretary explains, "are still orthodox and still sound, if only the application of 


\section{PROPHETIC VOICES ABOUT AMERICA}

them is not carried to such an extreme as really to interfere with the public welfare." The longer one looks at the explanation, the more clearly one perceives that laissez-faire doctrines are true precisely so far as they are true, - and the more strongly one is reminded of the classical advice of the Honorable Preserved Doe, in the "Biglow Papers," -

"A ginooine statesman should be on his guard, Ef he must hev beliefs, nut to b'lieve 'em tu hard."

One can't help wondering if Professor William Graham Sumner was in that audience; for it seems probable that Secretary Taft had in mind not so much the newer questions of government control of the great corporations as a very old question, over which the battle of laissez faire has been fought many times before. When the issue is on the tariff, it is still the unfavored many who possess that war-cry, still the favored few who importune Government for help. Two years ago, Secretary Taft spoke in a way to indicate that he held clear views about protectionism, and did not fear to express them. That he should now, both in this little book and in more recent utterances, give 


\section{PROPHETIC VOICES ABOUT AMERICA}

forth an uncertain sound on that issue, must prove a grave disappointment to many who have accounted themselves his well-wishers, to all who have been led to regard him as of the school of courage and candor in public life.

And here, too, if I mistake not, lies the plainest falling-short of the present administration in the eyes of its more disinterested supporters. Six years ago, President McKinley, “regular” Republican though he was, and while parties could demand regularity far more imperiously than they can today, said at Buffalo, in his last public speech, “The period of exclusiveness is past. The expansion of our trade and commerce is the pressing problem. Commercial wars are unprofitable. A policy of good will and kindly trade relations will prevent reprisals. Reciprocity treaties are in harmony with the times, measures of retaliation are not."

Theodore Roosevelt, who entered public life a tariff reformer, and who so long remained, and measurably still remains, the hope of independent and manly men inside and outside his party, solemnly promised, while McKinley lay unburied, to endeavor to carry out his policies. For six years we 


\section{PROPHETIC VOICES ABOUT AMERICA}

have waited in vain for President Roosevelt to affirm or to controvert the last and on the whole the most important announcement of policy President McKinley ever made. He has never moved in that matter, nor has he ever explained why he does not move. And now, as his administration approaches its end, the man whom he would have us take for his successor will go no further than to declare for tariff revision - after the election! That, of course, means, after the election of a Republican President and Congress. It means, therefore, revision by a House of Representatives under the control of Speaker Cannon, and a Senate under the guidance of Senator Aldrich. Will the American people be content to vote upon the issue in that form?

Mid-ocean should be a good place for broad and placid views of human affairs, and I happen to be writing at sea. But it happens also that I find on board ship an illustration of the actual working of our present tariff laws which well-nigh counteracts the sea's great soothing. Down in the hold are several thousand tons of American steel billets. They will be sold in England cheaper than they 


\section{PROPHETIC VOICES ABOUT AMERICA}

can be bought in America. Nor is this an exceptional incident; such cargoes are the rule. The last time we discussed the tariff, protectionists did not predict and did not defend this process of " dumping." Since then, writers like Mr. Edward Stanwood have, I believe, accepted it as an outcome of extreme protectionism, and defended it as a relief to an occasionally glutted home market. But has any one ever defended such juggling with the laws of trade as a regular practice? Certain it is that the American electorate has never approved it. Probably the mass of voters do not yet understand that our protected manufacturers are actually making a profit on goods sold in England cheaper than at home, and in competition for the home market of those very foreigners against whom we are taxed to protect them. The voters have not, in fact, had a chance to consider at all this new phase of our tariff policy.

For that, however, we cannot blame the party in power. The opposition has had all along, of course, the right to bring the question before the people, and every general election for the past ten years or more has presented an opportunity. But 


\section{PROPHETIC VOICES ABOUT AMERICA}

this weapon of attack has lain unused in the Democratic arsenal. Meanwhile Mr. Bryan (not to be outdone, are we to suppose, in astuteness by the other side ?) proposes to make government ownership of the railways the issue-but also, after the election! The tariff is again, as it would have been in 1900 or in 1904 , but even more plainly, the best fighting ground of the opposition. It is to be remembered that, as a matter of simple fact, they have never lost when they have forced and kept that issue before the people. But the opposition, apparently, has no memory. Failing a new leadership, which must mean a new leader, Democratic stupidity bids fair, once again, to equal or surpass the measure of Republican culpability.

Does this heat seem political - even partisan? But so much is pertinent, I think, to the line of discussion which all these writers follow. For all turn, in some fashion, to the endless theme of privilege, to the still unsolved problem of economic justice as an ideal of the state. With nearly all, this is the main theme - and in what sincere and disinterested writing about affairs is it not the main theme? I think, as I have said, that it is superficial, 


\section{PROPHETIC VOICES ABOUT AMERICA}

almost archaic, to write as if the last word were said about democracy when one has set liberty over against equality. But neither is that eagerness wisdom which, rushing to attack the newer positions of privilege, such as are challenged in our more recent legislation for the hampering of trusts by fuller control of railroads and other means of transportation, raises the siege of an older stronghold. Essentially the same power and process which manipulate railroads to the ends of monopoly a concentration of the selfishness of wealth-piled up, and to the same end, that extraordinary tariff wall which now, while it shuts out the foreign producer, lest he lower prices among us, leaves our own manufacturers free to serve free-trade England far more cheaply than they will serve their countrymen at home.

But it is well, of course, to take account broadly of all the aspects of privilege in the Republic, to consider candidly all theadvantages which wealth, by an utterly unexampled facility in aggregation and combination, has contrived to win. Wealth is not, it is true, the only form of privilege in America. There is the privilege of race, to go no further; 
but none of our writers is dealing with the case of the negro, the red man, the Asiatic. Moreover, the problems of that class, although vastly momentous and unspeakably difficult, are yet of a range something less than universal; they are also, I am persuaded, of an at least relatively diminished and diminishing importance. The struggle for ideals, for justice, is in the main and usually either a fight with overweening wealth or a leashing and beating-back from anarchy of the discontents and envies that spring from real or comparative poverty. Of course, therefore, the struggle in America is but part of a universal contention, and is distinct and peculiar only by reason of our democratic and federal form, and whatever else there is in our life to set us apart from other modern peoples.

Perhaps it should be accounted one of the peculiarities of our case that wealth cannot here, as in older countries, grace and ingratiate itself with claims of blood, with high traditions of conduct, with the records and memorials of historic sacrifices and heroisms. If we must admit that there is nowhere else so great a mass of wealth, so easily 


\section{PROPHETIC VOICES ABOUT AMERICA}

combined, to be reckoned with, at any rate it must also be said that nowhere else does wealth thrust itself so crudely before the vision. Nowhere else does so little of sentiment or reverence help to fight its battles. Nowhere else is its predaceousness so plainly greed.

The consideration is not negligible. England is to-day, as we all know, in many respects quite as democratic as America ; but whereas, even before our independence was achieved, and even in aristocratic Virginia, Jefferson could strike down the entire system of entails, it survives to this day in the mother country. Because the English people hold in real honor the great families whose names are forever associated with noble passages in their history, the greater part of the land of England cannot be bought, but passes on, generation after generation, from eldest son to eldest son, no matter how improvident its possessors. That the system works a continuing hardship to farmers whom it prevents from becoming landowners is patent. That we have been so long exempt from it is a true instance of our exceptional free-handedness in the struggle for that reasonable equality of op- 


\section{PROPHETIC VOICES ABOUT AMERICA}

portunity which I think we must account essential to the attainment of the substance of liberty.

Why, then, has wealth so great weight and power in our system? Taking it for granted, of course, that greed will in America forever play upon whatever weaknesses of universal human nature it elsewhere suborns, what, if any, are the more peculiar means which it may here make use of? In what concrete ways does it successfully combat our American ideals of liberty and independence, fair play, justice? To be more specific, what is the fault or weakness in this our American plan of government? Is it possible to strike one's finger on the spot? Or is the sickness general, spreading throughout all our veins and members?

This, it would seem, must be, of necessity, the main present inquiry about the Republic. It is true, as one of our writers is at much pains to show, that we began by deliberately granting to privilege what was thought a firm footing in our fundamental law, national and state; that our founders, for the most part, held this to be wisdom, and the only way to insure us stability. But their theory is long since abaudoned, and the particular fortifica- 


\section{PROPHETIC VOICES ABOUT AMERICA}

tions of privilege which they erected - such as property qualifications for the suffrage and for office - are nearly all long since swept away. Such dominance as wealth has now in our system may be regarded as a new kind of dominance, and exercised by a new kind - or degree — of wealth.

Where, then, is the breach? Nothing is more interesting, in the comparison of our several writers' views, than the almost unanimity of their answers to this question, so far as they definitely consider it. The Executive in our system has, they seem to agree, justified all the reasonable hopes of the founders. In State and Nation alike, the Chief Executive is, as a rule, a fairly true representative of the people's interests, at any rate of the people's will. The old fears that he would turn usurper, and suborn courts and legislatures to his ambition, have proved quite mistaken. Now and then a Governor, less often a President (Andrew Jackson is almost the sole instance), has been, for a little while, successfully imperious. But the Executive Department has not in the long run gained in power at the expense of the others. On the contrary, it has 


\section{PROPHETIC VOICES ABOUT AMERICA}

had much ado to hold its own. Quite as rare are the instances of proved corruption or faithlessness. Nor have the courts either unduly enlarged their function or betrayed their trust. It is with the legislatures that fault is found.

It is the legislatures, and particularly the national Congress, which have proved most rapacious of power and shown the strongest disposition to encroach upon the powers of other departments. "Ever since the Civil War," President Butler declares, "Congress has steadily invaded the province of the President." It has likewise, as he and President Hadley point out, thrust itself into the province of the courts; but in the nature of things this invasion could not go so far as in the case of the Executive.

Secretary Taft puts it with his habitual mildness. So far from the Executive's usurping legislative functions, "the tendency," he remarks, "is exactly the other way. The danger that the Executive will ever exceed his authority is much less than the danger that the legislature will exceed its jurisdiction." And he points out that, since the legislature holds the purse-strings, the President is 


\section{PROPHETIC VOICES ABOUT AMERICA}

always "a petitioner at the door of Congress for the means to carry on the Government."

President Hadley is not given to mildness, particularly with legislatures. "The legislature," he says, " not only fails of its primary purpose in making the right kind of laws, but perverts its secondary purpose by exercising the wrong kind of checks upon the Administration. A representative can exact a price for his support of the Administration in a matter of public interest, and the more the public interest is concerned in the passage of the measure, the higher the price he can charge." And both he and Professor Reinsch dwell upon the tendency of all our legislatures to multiply laws on every subject that can be thought within their jurisdiction; a tendency which has forced the courts, although at first inclined to be timid, to a freer and freer exercise of their right to pronounce statutes unconstitutional, and which has led the States to impose, by constitutional conventions, countless new limitations upon the activity of their lawmakers.

President Butler goes back to Madison for a rather cautious prediction of what has happened. 


\section{. PROPHETIC VOICES ABOUT AMERICA}

He would have done better to take this striking prophecy of Gouverneur Morris, in a letter to a correspondent who asked a question about the Constitution :-

That instrument was written by the fingers which write this letter. Having rejected redundant and equivocal terms, I believed it to be as clear as our language would permit; excepting, nevertheless, a part of what relates to the judiciary. But, after all, what does it signify that men should have a written Constitution, containing unequivocal provisions and limitations? The legislative lion will not be entangled in the meshes of a logical net. The legislature will always make the power which it wishes to exercise, unless it be so organized as to contain within itself the sufficient check. Attempts to restrain it from outrage, by other means, will only render it more outrageous. Having sworn to exercise the powers granted, according to their true intent and meaning, they will, when they feel a desire to go farther, avoid the shame if not the guilt of perjury, by swearing the true intent and meaning to be, according to their comprehension, that which suits their purpose. ${ }^{x}$

And it is the legislatures which have proved most pliable to the demands of privilege, of wealth. On this point there is no dissent. "It is to the committee rooms and the floors of the legislatures,"

- Gouverneur Morris to Timothy Pickering. Sparks's Life of Gouverneur Morris, vol. m1, p. 323 . I am indebted to two friends, Mr. T. H. Clark and Mr. W. C. Ford, of the Library of Congress, for this quotation. 


\section{PROPHETIC VOICES ABOUT AMERICA}

President Butler declares, " that private interests go for help or protection. There responsibility is so divided, there secrecy is so easy, that measures demanded by the people are done to death, despite the urging of national and state Executives. As matters stand to-day, States and syndicates have Senators, districts and local interests have Representatives, but the whole people of the United States have only the President to speak for them, and to do their will." Secretary Taft is again the mildest. All he will say is, "I do not mean to deny that at times private and special interests do, in fact, exercise an influence to the extent of defeating needed legislation." But he agrees with the others that the chief reason for this, as for the general failure of the legislatures to be rightly representative, lies in the control which particular States and other electoral districts exercise over members. "Particularism" is, I suppose, our only word for this phenomenon. Professor Reinsch lays much stress upon it, but President Hadley has given it the most attention and goes at the greatest length into the analysis of it and the settingforth of its consequences. 
PROPHETIC VOICES ABOUT AMERICA

The upshot of his analysis is that, with comparatively rare exceptions, the old theory that every legislator represents the whole country or the whole State, as the case may be, is practically abandoned. The theory now would seem to be that it is enough if each merely looks after the interests of his own district. Nowhere in the legislatures is there clearly placed any responsibility for the welfare of the entire body politic, and nowhere (since we have not the English device of a responsible cabinet) is the responsibility clearly placed for the entire body of legislation enacted by a particular Congress or general assembly of a State.

By two steps, President Hadley reaches the practical outcome. "If a man is chosen President to govern the country as a whole, and if a number of men are sent to Congress to see that the country is not governed as a whole, but with a view to the interests of the separate parts, there is a perpetual threat of a deadlock." That means, according to the writer's conviction, - which is not, however, fully announced in this book, - the failure of representative government. The second step is logical, if surprising. "But the country 


\section{PROPHETIC VOICES ABOUT AMERICA}

must be governed, and somebody must be found to do it. The President may not do it. That stands in the Constitution. Congress may not. That also stands in the Constitution. The only man left to do it under present conditions is the party boss. If a man gets the power to control nominations both for the executive and the legislature, he can furnish government of the kind he wants, either good or bad."

Here, no doubt, is an instance of the academical too great "certainty and severity" of reasoning about affairs. An overstrained major premise is made to yield an inference at once too broad and too precise. In practice, the instinct of compromise is far too strong, and compromise too potent a resource, to permit of anything like a constant and complete deadlock between legislature and executive. Both yield much, and together they so often contrive, without other help, to carry on the government, that the boss is neither omnipresent nor, when he exists, omnipotent. Nevertheless, one does recognize the physiognomy thus so candidly traced as a kind of composite portrait of representative government in America. 


\section{PROPHETIC VOICES ABOUT AMERICA}

We shall not easily agree upon any statement of the extent of the evil. Sincere men will vary all the way from Secretary Taft's mere acknowledgment that there is something the matter to the journalese of Mr. Lincoln Steffens, - " government of the people, by the rascals, for the rich." But the evil stands confessed, proved, explained, - and few of us would deny that it is of great enough proportions to make us all ashamed.

Naturally, it is the Socialist of our group who is disposed to make the most of it. It is difficult, in fact, to imagine how he could make any more of it than he does. "The process culminated," he tells us, " at the beginning of the present decade, when 'big business ' was in practically undisputed possession of both the major parties, of Congress and the presidency, and of the governments in every town, city, and State in America."

I think that we should not take Mr. Sinclair as a fair representative of the socialist thought of our time. Certainly, he does not appear to good advantage in comparison with the writers with whom I am here associating him. When we turn from almost any one of them to him, his rhetoric seems 


\section{PROPHETIC VOICES ABOUT AMERICA}

cheap, and much of his reasoning irritatingly ad captandum. Irritating also is his loose, irresponsible handling of matters of fact, his positive assertion of things quite incapable of proof, - as when he states that Roosevelt got a second term in 1904 only by the death of Senator Hanna, - and such outbursts of undisciplined feeling as his heaping of rather vulgar epithets upon the German Emperor. But his book may perhaps serve at least to indicate the socialistic view of the most recent phases of our political and economic life.

His main contention is that practically all the ills which we now endure as a community - not the political ills only but the economic and the social as well - are the outcome, and the perfectly logical outcome, of the régime of competition, under which a few private individuals have at last gained possession of all the means of production. The subversion of government is but one phase of the racking and squeezing which society must continue to endure so long as capital, omnipotent, shall continue to demand profits.

This, of course, is not new. Nor is there anything new in his remedy - the extinction of pri- 


\section{PROPHETIC VOICES ABOUT AMERICA}

vate ownership of capital and the taking-over by the community of all the machinery and other appliances of industry. Nor yet does it seem a new thing to be told that we are come to a crisis, and that the "revolution" is at hand. It provokes a kind of smile, indeed, to remember how many times society has been told that it was passing through a "transitional stage," how constantly " the present crisis" has been discovered. And not by socialists only; it would almost seem that men cannot write earnestly, with feeling, about society, without discovering a crisis. But Mr. Sinclair contrives to give some novelty to his contention. One of his chief devices is a curious parallel between the present "present crisis" and that other crisis of the fifties out of which came the revolution that overthrewslavery; and his journalistic instinct is keen enough to furnish forth the parallel with incidents which make it readable. The revolution is to come within a year after the presidential election of I 9 I 2 . (The author admitted that it might come this past summer, - the book was written in the spring, - but he is entitled to the credit of having clearly preferred the later 
PROPHETIC VOICES ABOUT AMERICA

date.) To Secretary Taft, as President from I 908 to I 9 I 2, President Buchanan's rôle of " the last figurehead" is assigned, while the parts of other leading actors in the earlier crisis - Webster, Clay, Sumner, John Brown, and the rest - go to various living celebrities ranging in quality from former President Cleveland to Mr. Jack London. Lincoln, we may be sure, is not neglected. $\mathrm{He}$ will find his counterpart as an emancipator in $\mathrm{Mr}$. W. R. Hearst, of the New York "Journal " and various other newspapers. ${ }^{\text {I }}$ Even the method and process of the revolution are quite frankly revealed; Mr. Sinclair is not a secret conspirator, but, as he announces in his preface, "a scientist and a prophet."

If one were compelled, with no prompting of personal grievance, to choose between this and even the most conservative, the most placid view

I Whose modesty, let us trust, has not led him to forbid the editors of those papers to make mention of this tribute to their owner. It is to be hoped also that, while not failing to mention with approval the volume which contains this illuminating comparison, Mr. Hearst's papers have pointed out that it is Mr. Sinclair's novel, The Fungle, - not The Industrial Republic, - which, as Mr. Sinclair himself informs us, has been compared to Uncle Tom's Cabin. These are points on which, after the revolution, school children ought not to be misled. 


\section{PROPHETIC VOICES ABOUT AMERICA}

of the Republic to be found in any of these writers, it is hard to see how one could hesitate. Such hurried reasoning, so suffused with feeling, can only prevail, one would think, with minds already filled with such a wish for change as will readily father the thought of revolution. But there are quieter socialists than $\mathrm{Mr}$. Sinclair, who make their way by more careful steps to revolutionary views of society; and there are men with no bent whatever toward socialism who feel much as he does about the competitive system in its present phase and its effects in our American life.

All the writers of our group, indeed, go so far as to admit that we must deal henceforth with conditions and with forces which our founders did not and could not contemplate; that our system must therefore, if it is to endure, withstand a new kind of strain, perhaps discharge new functions. "Our political system has proved successful under simple conditions," says Secretary Root. "It still remains to be seen how it will stand the strain of the vast complication of life upon which we are now entering."

Does the admission mean that we must intro- 


\section{PROPHETIC VOICES ABOUT AMERICA}

duce into it any new principle or principles? that Lowell was wrong, and really begged the question, when he said that the Republic will survive so long as it shall adhere to the principles of the founders? That is the drift of much writing and speaking nowadays. It is one form, apparently, of the reaction which takes place in many minds when they find they must give over the comfortable assumption that all the great constitutional questions are settled, that no problem of free government can prove really troublesome to people who have already attained civil and religious liberty, the ballot, the public school.

It is not, however, the view of Secretary Root, who of all the conservatives of our group makes the most systematic attempt at a forecast of the future. On the contrary, he is clear that we shall need no new principles whatever, but only " the adaptation of the same old principles of law with which our fathers were familiar." True, the Secretary confesses that he regards optimism as the plain duty of every citizen and pessimism as "criminal weakness"; but his quiet recital of what he considers favorable signs for the future of free 


\section{PROPHETIC VOICES ABOUT AMERICA}

government in America is quite without the objectionable quality one finds in Mr. Sinclair's prophesying.

Secretary Root looks to tendency, rather than achievement; and he is hopeful, not because he finds our public life as it should be, but because he does find it - undeniably lamentable as are some of its aspects - measurably better than it has been. $\mathrm{He}$ enumerates our gains. We have vastly improved our civil service; the several extensions of the merit system have deprived the spoilsmen, the office-brokers, of the greater part of their stock-in-trade. We have won for both life and property far greater security than they had at the time of our beginnings. We manage our benevolent institutions better and better. We have raised the standard for nearly all elective officials; an Aaron Burr, for instance, could hardly be chosen nowadays to the vice-presidency. We have been so far successful in the long fight against corruption that the scandals of President Grant's time - the Crédit Mobilier fraud, the peculations of Belknap, Secretary of War, the Whiskey Ring, the Tweed Ring - have to-day no counterparts. 


\section{PROPHETIC VOICES ABOUT AMERICA}

We have gradually developed a public opinion which would utterly condemn practices that were quite common a century ago, such as the use of lotteries to secure money for seminaries of learning. We have begun to mulct railroads for granting rebates to favored shippers, and to prosecute great capitalists for manipulating railroad and other corporations to their own interests, - offenses which long went unpunished. We have similarly begun to take account of the thefts of our public lands. We have done much, by the Australian ballot and other measures of reform, to prevent corrupt practices at elections.

These gains are real and substantial; this there is no denying. But are they enough? Are they enough to offset the positive reasons for discontent enumerated by Mr. Sinclair and by abler writers? Are they enough, if we adhere to Secretary Root's own point of view, and consider only tendency, direction, to offset such a list as might be made of the respects in which we have lost rather than gained?

For we must observe that Mr. Root says nothing of that. He does not strike a balance, or show 


\section{PROPHETIC VOICES ABOUT AMERICA}

us the other side of the picture. Yet he would hardly deny that something discouraging may be said on this very point of tendency, of direction, which he emphasizes. Socialists may be wrong when they tell us the poor have been growing poorer, but they are not wrong when they tell us that the rich are growing richer. Neither are those writers wrong, on the other hand, who point out that the new organization of industry into prodigious trusts, real as may be its economies, tends to stifle the enterprise of individuals and to deprive us altogether of a certain noble and loving quality in work, as precious to the workman as it is invaluable and inimitable in his product. Nor are they entirely wrong who find in the labor unions a well-nigh equal tendency to destroy the premium which an elder régime put upon the industry and the competence of the individual laborer. Nor yet are they wrong who hold that these tendencies away from excellence in industry work their way also into the life of the State.

It is a question of gains and losses, therefore; not of gains alone. We cannot reckon upon any 


\section{PROPHETIC VOICES ABOUT AMERICA}

saving inertia in the Republic which will always incline it toward justice and righteousness, save as the wicked and selfish among us may divert it to their evil ends. On the contrary, the labor of reform keeps still its Sisyphean character; the stone that patriots toil so hard to roll upward will always, once they remove their shoulders, slip back downhill again.

Perhaps we have not yet, we Americans, fully considered how long humanity has been at this endless task; how many shoulders have been at the stone; how many times it has gone painfully upward; how many times, how suddenly, over what anguish and despair and shame, it has rolled downward. Were we always to keep in mind the entire past of representative government and of democracy, we should often, I doubt not, tremble at the thought of the vastness of our audacity. We should wish, perhaps, that we had willed to try our experiment on a smaller scale; that we had waved back the millions of Europe's baffled and beaten who have thronged across the Atlantic to our shores; that the other millions left behind would not still look to us so wistfully, as though 


\section{PROPHETIC VOICES ABOUT AMERICA}

we were condemned to bear the burden of the whole world's hope in democracy.

This might well be one's mood as one considered it all, - but not if one considered it at sea.

How inevitably, if one thinks long of the State, the old figure of the ship recurs! And how surely, if in thought or in fact one looks out upon the ocean, and forward to the prow, rising and falling, and backward to the vessel's foaming wake, and upward to the bridge, one's mood grows firmer, more heroical! How surely, also, when one is at sea, do human affairs, with all their bewildering intricacy, sink away into that right perspective which permits the mind to dwell resolvedly upon the elementary, the elemental things! There, no willful optimism can blot out the dreary vision of human selfishness, as tireless and hungry as the waves; of human folly, as restless and as inconsequent ; of human misery, as widespread and as ceaseless. But neither can any coward awe obscure the shining truth that over all the ocean's moods - its mists and storms, no less than its tranquillities - the ship is victor. And the mind, guided by that thought, rests upon the primal, 


\section{PROPHETIC VOICES ABOUT AMERICA}

saving facts of human courage, wisdom, hope unconquerable, - even as he who walks the bridge and finds the ship her course is fearless, knowing that he has always the compass and the sextant, the sun, the stars.

1908. 


\section{THE WHITE PERIL}

THE IMMEDIATE DANGER OF THE NEGRO 


\section{THE WHITE PERIL: \\ THE IMMEDIATE DANGER \\ OF THE NEGRO}

N a recent tour of the Southern States, from Virginia to Texas, I took with me two pictures of Southern civilization at earlier periods. One was Frederick Law Olmsted's record of his travels in the South near the close of the slavery régime - a series of volumes which John Morley and the late E. L. Godkin have both thought worthy of comparison with Arthur Young's "Travels in France." The other was my own abundant memories of Southern life in the period immediately after Reconstruction.

Comparing my present-day observations with these two presentments of the past, I was convinced that a very important and a very deep change in the basis of the entire industrial system of the South is quietly in progress. For confirmation, I have turned to the elaborate and painstaking 


\section{THE WHITE PERIL}

Report on the Negroes which has recently issued from the Bureau of the Census at Washington. Confirmations of a sort I do seem to find there; but it is extremely doubtful if from that source alone I should ever have derived my conviction. In presenting it, therefore, I shall rely rather on the concrete observations of my journey than on the figures which may seem to sustain them. These would not have their full value nor their true significance unless one applied them ceaselessly to a mental picture of the South as it is, and to Southerners as they are, and to negroes and mulattoes as they are - not to dehumanized "whites" and "blacks."

It is a century, perhaps, since Virginia ceased to be the main source of the controlling tendencies of Southern life. Her soil is no longer the best ground for the study of the civilization which had its rise there. Geography, however, abets the suggestion of history that any examination of the South should begin there: and, if one is looking particularly for signs of economic and industrial change, Virginia is by no means to be neglected. It is doubtful if in any but the very youngest of 


\section{THE WHITE PERIL}

the States deeper social changes could be observed than in this, the oldest.

Two movements of population are, perhaps, the most important: an exodus and an immigration. There is a steady and widespread movement of negroes from the countrysides into the towns, and out of the State into the North; and there is a moderate but fairly steady, and apparently increasing, inflow of whites. The gain of whites from without is not, it is true, so rapid as in many other parts of the country. The rate is probably below the average for the Atlantic tier of States. Neither is it equal to Virginia's present capacity and demand for white population: for there is much waste land within her borders that would yield a fair return to careful husbandry, there are many still untrodden avenues to wealth. But it is certainly interesting to learn that farmers from the far Northwest are coming nowadays in considerable numbers, sometimes in little colonies, to make their homes on the banks of the James and the Potomac and the Roanoke. What is still more significant is that some portion of our immense immigration from Europe is at last being diverted, 


\section{THE WHITE PERIL}

be it only in driblets and wavelets, from the great Eastern cities and the growing States of the West and Northwest to the oldest of all the Southern States.

And it is not unreasonable to hope that immigration of both these kinds, which for a century and more the South has in vain desired, may continue to increase. The movement of the blacks townward and northward is so widespread and persistent that it is only natural to wonder who will take their places on the farms. All over the State, complaints are heard of the scarcity of agricultural labor. Equally common is the complaint that the negro as a laborer, particularly as a farmhand, is deteriorating. It is harder and harder, one hears on all sides, to bind him to the soil or to long terms of service in any line; and he is likely to leave at the very seasons when the farmer needs him the most. The situation - taken with the fact of an increase of immigration - suggests the curious possibility of a sort of second colonization of the oldest of all our shores.

Even in the cities, though the proportion of negroes in the urban population has not declined, 


\section{THE WHITE PERIL}

it is plain that more and more white men are turning to kinds of work which used to be done by negroes only. In domestic service, it is true, this is not the case; and in justice it must be said that of all negro domestic servants the best are doubtless to be found in eastern Virginia. The negroes of that region have profited by the longest training - and in the best school of manners - that any portion of the race has ever anywhere received. But it is plain that the whites are gaining in the shops and mills and factories, and in many other employments, in the Virginian towns. In the cities, workingmen's suburbs, where the children one sees about the doors are white, are growing quite as fast as the quarters given over to negroes. This, it may as well be said at once, is true also of the cities in other parts of the South.

In the cities and towns of the Carolinas, where such a rapid progress has been made in the manufacture of cotton and of tobacco, these tendencies are even more strikingly exhibited. The new industrial movement in those States has been strongest in the interior counties, particularly in what is called the Piedmont section. The Piedmont 


\section{THE WHITE PERIL}

country has always been the habitat of the small white farmer; and it is people of this class in whom and by whom the important changes have been wrought. It is chiefly they who have manned the new mills and factories, populated the new manufacturing towns, and increased so rapidly the population of the transformed older towns. To any one familiar with the old Southern class distinctions, this will be apparent from the briefest visit to such a place as Charlotte, in North Carolina, or Spartanburg, in South Carolina. The newcomers, it is easy to see, are "up-country folks"; and according to the nomenclature of his own particular quarter of the South the visitor will set them down as "Crackers," as "Moss-Backs," as "Red-Necks," as "Hillians," as "Coveites," as "Wool-Hats," or as " Copperas-Breeches."

True, there are negro quarters in all the larger towns of the Piedmont region, though not in the cotton-mill villages. It is true also that there are negroes employed in the tobacco factories. In these establishments, in fact, one finds them at work side by side with the whites, frequently on the same piece and at the same machine. That 


\section{THE WHITE PERIL}

is a phenomenon which might have been observed in Richmond also. It is nowhere in the South quite so common a sight as to suggest the lying down together of the lion and the lamb. If, however, we consider it with a right historical perspective, the real sign of change is in the white man's being there, not in the presence of the negro.

In the cotton-mills, the negro is not found at all. A few years ago, one could have found him in a mill at Charleston, owned and managed by white men. Until a few months ago, he could also have been found in a little mill at Concord, in Nor th Carolina, owned and managed by members of his race. But with the failure of these two experiments he seems to have disappeared entirely from the cotton industry of the South Atlantic and South Central States. The only cotton-mill in the entire South which now employs negroes is, I believe, at Dallas, Texas. ${ }^{\text {t }}$ Mean while, to meet the demand for mill-hands in the Carolinas alone, from fifty to a hundred thousand white people have given up other employments, - mainly, no doubt, farming.

I A silk-mill at Fayetteville, North Carolina, operated by negroes, is said to be successfuil. 


\section{THE WHITE PERIL}

The failure of the negro to find a place in this industry, now firmly established in the South, and growing with an amazing growth, is too big a fact to be taken without some scrutiny of the tests by which his unfitness for it seems to have been established. At least two very high authorities are decidedly of opinion that the trials which have been made of negro labor in the cotton-mills are by no means conclusive. The president of half a dozen large and successful mills points out ${ }^{x}$ that the experiment at Charleston was made under conditions which would probably have been fatal even if white labor had been employed. The industry never has taken root in the coast towns, nor, indeed, in any old urban community like Charleston. It is understood that the machinery of the Charleston mill was old; and a principal advantage of the Southern mills in general is that their machinery is of the newest and the best. The labor employed was not carefully selected, or in any way segregated. The chances are that the capital behind the enterprise was inadequate. That was also the case in the experiment at Concord. In this view, Prin-

1 In conversation with the writer. 


\section{THE WHITE PERIL}

cipal Washington, of Tuskegee, concurs.' He believes that negro labor could be successfully used under the conditions which have been found essential with white labor: that is to say, in a segregated mill settlement, owned and controlled by the owners of the plant, and with adequate capital, competent management, and new machinery.

In this reasoning there is much force. But a lost battle is not restored by proving that it ought to have been won. It may not help the matter to explain that the field was unfavorable, the tactics bad, the odds unfair. Insufficient and inconclusive as the tests have been, the event may prove that the negro's chance in the cotton-mills is, none the less, lost forever. The mill president whose view has been given is not desirous of seeing the question reopened. The industry is in a good way as it is. The South is rapidly gaining on all the other centers of it. Every year, the white labor employed in the mills grows more and more skillful. It is also being trained systematically for the manufacture of finer and finer grades of cottons. Moreover, usage is fast hardening into custom, and custom

\footnotetext{
1 In a letter to the writer.
} 


\section{THE WHITE PERIL}

soon makes rights. It is now quite probable that the Carolina mill-hands would instantly rebel at any such association with negroes as the operatives in tobacco factories accept as a matter of course. The superintendent of the largest mill in the Carolinas is positive that if a single negro operative were brought into it every man, woman, and child in the establishment would walk out. Even if no attempt were made to introduce negroes in the same mills with whites it is by no means certain that the whites would endure their competition.

The reader, no doubt, begins already to understand the nature of the change in the South's industrial system which my journey was by this time leading me to think that I perceived. What the Carolinas seem to exhibit better, perhaps, than any other part of the South is the rapid emergence of the native poor whites, the South's great unutilized industrial reserves, from the narrow limitations which slavery set them, and which nearly three hundred years of ignorance, inertia, and prejudice had strengthened into a Chinese wall of hopeless conservatism. They have come at once into competition with the negroes, - either direct, and on 


\section{THE WHITE PERIL}

fairly equal terms, as in the tobacco factories, or indirect, and far more fatal to the negroes, as in the cotton-mills. What at present appears is that they no sooner entered into this great industry than the negroes were excluded from italtogether. The victory is signal. The effect of the exclusion on the negro's future can scarcely be overestimated. But this is only one of the many advantages which in the townward movement, strong in both races, the poor white is winning in the search for town employments. It is certainly not unreasonable to associate these facts with the other movement among the negroes - the movement northward.

Of that, however, less is heard as one travels farther southward and southwestward. Florida is evidently gaining negroes fast by migration, and the movement southwestward, to the prairies and river-bottoms of Mississippi, Louisiana, and Arkansas, continues fairly steady. Nevertheless, in the cities and towns of the Lower South also, even in those of the Black Belt, it is apparent that the white people are changing their attitude toward the manual occupations. For one sign of the change, white barbers are now common, even in 


\section{THE WHITE PERIL}

the smaller country towns. Twenty years ago, they were extremely rare outside of the real cities. A still more striking innovation is the occasional employment of white women, presumably from the up-country, as chambermaids in hotels - even, in one instance, in a hotel where the other servants are colored. It was left, however, for New Orleans, the largest of all distinctively Southern cities, to exhibit the general change more variously and convincingly than any other.

The population of $\mathrm{New}$ Orleans is peculiarly good material for the study of race relationships. The mixture, not of races merely, but of customs and standards, of traditions and ideals, is extraordinary. Yet it does not require a long observation of the present situation there to make one feel sure that the African has lost ground relatively to all the rest. It is possible now to live in New Orleans as free from any dependence on the services of negroes as one could be in New York or Boston. The supply of white domestic servants is, no doubt, still scant. But white cooks and waiters are not very hard to find; and white barbers and hairdressers, white carpenters and joiners and masons 


\section{THE WHITE PERIL}

and blacksmiths and shoemakers, and the like, are at hand in sufficient numbers. Bricklaying is by a competent authority ${ }^{1}$ declared to be the only trade which the negroes still control. The contrast in these occupations with the very recent past is fairly startling. In 1870 , the city directory showed a total of 3460 negroes at work as carpenters, cigarmakers, painters, clerks, shoemakers, coopers, tailors, bakers, and blacksmiths and foundry hands. There are not to-day ten per cent of that number of negroes employed in the same trades, several of which have been completely lost to the whites. Yet, meanwhile, the negro population of New Orleans has increased by more than fifty per cent, - a greater gain than the white population shows. The mass of the negroes are now enrolled in the occupations which require the least intelligence and skill, the class called merely "laborers" absorbing thousands.

It is actually held that in property and in social station, as well as in industry, the negroes of $\mathrm{New}$ Orleans are worse off to-day, relatively and abso-

- Mr. Norman Walker, of the Times-Democrat, whose knowledge of New Orleans, past and present, is most thorough. 


\section{THE WHITE PERIL}

lutely, than they were in the year 1860 . The statement may be misleading, however, unless one takes account of the unique place which the city held in Southern civilization while slavery persisted. It was the Mecca of free negroes. The Latin element in the white population was proportionally stronger than at present; and as a rule the Latins do not treat negroes as Anglo-Saxons do. Nowhere else in the South could a man with a single drop of African blood in his veins attain the degree of social acceptance which a considerable class of mulattoes enjoyed at New Orleans. A peculiar local custom went far to account for this, and for the material well-being, the intelligence, and the refinement of manners, which the New Orleans mulattoes frequently displayed. From an early period in the history of the town, a system of concubinage prevailed there, which was quite unlike the ordinary illegitimate intercourse between the races. Arrangements with something of the character of morganatic marriages were common. The children of such unions were usually well taken care of, and often highly educated, not infrequently at Paris. Abroad, they 


\section{THE WHITE PERIL}

easily passed for white. At home, they had a social life of their own which was not without grace and elegance. But they enjoyed none of the rights of citizenship, and were always enumerated as negroes.

There is no more curious effect of emancipation than the fate which has befallen the survivors and the descendants of this unfortunate class. Their habits and training under slavery had unfitted them for the opportunities which freedom brought; and freedom denied them the peculiar place which slavery had kept open. Some of them made their way to France, where it is probable that their origin is not known. But the greater number were simply driven into the negro quarters of the town; and there they have gradually lost their separateness and ceased to be a class. The faces of their children are darker than theirs; their grandchildren's, darker still. The airs and graces of the half-world are gone, along with the occupation they were won and worn in. Its shame and its curious distinctions and privileges have been lost together. It must be added that what is true in this peculiar way of New Orleans is true 


\section{THE WHITE PERIL}

in another way of the other cities of the South. In the lowest of all human competitions, the woman of Africa succumbs to a rivalry more artful and more shameful than her own.

To these general tendencies of town life the towns and cities of the Southwest offer no exceptions. As one passes beyond the coast belt of Texas, the proportion of negroes rapidly lessens, but their preference for the town over the country is even more marked than it is to the eastward. The planters declare that it is impossible to hold them on the plantations. Yet in the towns it is said that the majority of them subsist on the earnings of a small minority who are at work, the women doing more than their part, chiefly as servants and laundresses. For the coming of white men into manual employments is even more marked in Texas than in the older Southern States. As a rule, they control the city trades completely. In Houston, for instance, it is said that the unions would not stop at force and violence if the negroes offered them any troublesome competition.

That, however, is not the situation in most Southern cities. As a rule, the relation of the 


\section{THE WHITE PERIL}

trades unions to the race question is quite different; and the writer must confess that the forces engaged in this particular quarter of the field have aligned themselves in a way which to him was altogether surprising. His expectation was that, sooner or later, the negro being excluded from the unions, the race prejudice would reinforce the union man's hatred of the scab, and the labor question would thus take on in the South a character more savage and dangerous than it has ever had in the North. But in this forecast something in the human nature of one or the other race, or of both, was overlooked. The negroes have never ventured into any serious rivalry with the white unions. They do, it is true, form unions among themselves, which are, as it is said, "affiliated" with those of the whites. But what this means in practice is that both unions are controlled by white men. Even when the whites in a particular trade or a particular establishment are only a minority, they have their way. Negroes rarely or never offer to take the place of white men who strike or are locked out. The explanation doubtless is that, with good reason, they fear white men of the working class 


\section{THE WHITE PERIL}

worse than they fear employers and capitalists, who frequently belong to the class so often described as the natural protectors of the blacks. It seems to be a fact that white workingmen from the North are more bitterly opposed to sharing any occupation with negroes than the native whites are. However, the situation in the Southwest may indicate that when the whites have sufficient numbers to monopolize the city trades they will incline to exclude negroes altogether.

All these things might be true of the towns, and the negro might still be reasonably safe if in the country his place were secure. Southern civilization is still markedly rural. The country still greatly outweighs the town in wealth and in population.

But there is much in the country to strengthen the general inference one naturally makes from what appears in the towns. In the country, also, white men are doing more and more of the work that was formerly left to negroes.

This is particularly true of those parts of Virginia and the Carolinas whence the negroes are migrating northward so steadily. There are even 


\section{THE WHITE PERIL}

instances, in those quarters, of large planters and landowners who now make it a rule to have neither negro laborers nor negro tenants, aiming especially to guard against sudden departures. Wherever the new régime has been thus candidly accepted, it seems unlikely that the old will ever be restored. Once free of their long dependence on the African, these people will hardly go back to it of their own accord.

But it is still more important, in any forecast of the future, that one finds a tendency to displace the negro farmhand and the negro tenant in regions where it cannot be attributed to a voluntary withdrawal of the negroes. If it were not so, one might incline to explain the general invasion of manual employments by white people on the ground of mere necessity, since there is more work to do nowadays than ever before in the South, and relatively fewer negroes to do it. The tendency does appear, however, in quarters where the negroes are increasing, increasing by migration, increasing faster than the whites. It is observable in such strongholds of the African laborer as the Black Belt of Georgia and Alabama, the Yazoo- 


\section{THE WHITE PERIL}

Mississippi Delta, the valley of the Brazos in Texas.

It is not, in these quarters, the native poor white with whom the negro has to reckon. The upcountry people, though they are coming into the towns, show little disposition to invade the prairies and the river-bottoms. It is the European, sometimes the German, but oftener the peasant of southern Europe, particularly the Italian and the Bohemian, whose competition the negro of the cotton and rice and sugar belts, if he were wise, would now be learning to fear. In Texas, he encounters the Mexican also; and, here and there, one hears talk of trying Chinese coolies. But the real threat is from the South of Europe.

Unfortunately, we do not know the proportions of this immigration into the South; but after a survey of the field I am sure that it is already considerable, and the signs are that it is also fast increasing. That is the opinion of railroad and steamship officials and of immigration agents. Even in the towns, effects of it are easily discernible. At least one great railroad system has begun to use Italians instead of negroes for track work, 


\section{THE WHITE PERIL}

as is done so commonly in the North. The newcomers are also finding their way into mills and factories. But nothing will impress so deeply any one familiar with the life of the Lower South as their appearance in the sugar-fields, the rice-fields, and the cotton-fields.

To understand how the inroad has been made and what it may conceivably herald, it is necessary to understand what the present-day plantation of the Lower South is like. A series of changes has transformed it into a very different affair from what it was under slavery, and for some years after the war. In place of the old-time planter, there is now a landlord. In place of the slave or the hired laborer, there is a tenant : sometimes a "cash tenant," paying a fixed money rental, but oftener a "share tenant," paying his rent with a part of the crop. Instead of a single and single-headed patriarchal community, there are a number of little farms under one ownership. It is true that the landlord retains, occasionally by contract, universally by custom, many of the rights of supervision and control which he had as a planter. He or his overseer is constantly in- 


\section{THE WHITE PERIL}

specting, advising - in effect, commanding. $\mathrm{He}$ usually keeps in his own hands the fencing and draining and general up-keep of his land. It is more than likely that he advances the tenants their supplies. He may even own the tenant's tools and stock, as well as his cabin. Sometimes his control is so nearly complete that it might be more correct to describe the division of the crop as a payment by him to the tenant for his services than as a payment by the tenant to him for the land. Of course, there is also the small independent farmer, white or black. But the share-tenant plantation is the typical agricultural community of the Cotton Belt.

One of the earliest attempts to introduce the peasant of southern Europe into this system was made twelve years ago, by the late Mr. Austin Corbin, at Sunnyside Plantation, on the Arkansas side of the Mississippi River. A colony of Italians was brought over, and established in tenantry under contracts which looked to the final purchase of their holdings. Mr. Corbin died, however, before the enterprise was well under way. The men in charge of it were not, it is understood, 


\section{THE WHITE PERIL}

familiar with local conditions or experienced in plantation management. As first planned and conducted, it failed. But with the failure came a change. Men to the manner born were put in charge. It can be stated to-day, on the best authority, that the experiment of tenant-farming with Italians at Sunnyside is successful from the point of view of the managers and owners, brilliantly successful from the point of view of the immigrants themselves. They have mastered quickly what they had to learn about the growing of cotton and the other crops. They have endured the climate. They have proved both more industrious and more thrifty than the negroes about them. Though they began with nothing, a number now own the land they cultivate. Several have bank-accounts running into the thousands. Some are sending money home to pay debts or to bring over their kin.

It is probable that the Sunnyside colony was selected with some care, and from the thrifty peasant farmers of the interior of Italy. Quite likely, therefore, these people are superior to the mass of Italian emigrants to this country, drawn mainly 


\section{THE WHITE PERIL}

from Sicily and the lower end of the Peninsula. But what has happened at Sunnyside is happening at too many other places to be regarded any longer as extraordinary. One instance is carefully described in a Bulletin of the Bureau of Labor. ${ }^{\mathrm{I}}$ At Calumet, a sugar-plantation in Louisiana, none but negro labor was employed up to eight years ago. Since then there has been a gradual displacement of the negroes by Italians. It does not appear that either there or at Sunnyside the blacks are stimulated by the example and competition of the newcomers to work harder or to save money. It is found, too, that more Italian than negro children work in the fields, and at harder labor. I have heard of Italian tenants who, after harvesting their own crops, have hired themselves as cottonpickers to negro tenants who were behindhand. It has come to be a common saying, where the ways of both races are known, that if an Italian earns a dollar and a quarter he will spend the quarter and save the dollar, but that if a negro earns the same amount he will spend - a dollar and a half.

1 No. 38. The Negroes of Cinclare and Calumet. By J. B.'Laws.

2 Italian emigration to the South seems at present to be entering on a 


\section{THE WHITE PERIL}

The Italian as laborer and tenant on the plantation of the Lower South is no longer an experiment. It is clear that as a rule he does the work at least as well as the negro, and that he is more likely to save money and become a landowner. The testimony concerning Bohemians is quite as favorable. The success of the large German colonies in Texas, Alabama, and other parts of the South has long been established. Yet it is true that many planters, probably a majority, still prefer the negro, and particularly the uneducated negro, both as laborer and as tenant.

Explanations, however, are not far to seek. There is custom, tradition, prejudice. There is, in most cases, a genuine fondness for negroes. There is the habit of command, to which the negro makes the least resistance. Moreover, by the system of advances, the planter can be reasonably sure of ob-

new phase. Acting for the Italian Government, II Cavaliere A. Rossi and G. Rossati and Professor A. Ravaioli have been carefully studying the opportunities which various sections hold out to their countrymen, particularly to agriculturists. Their reports are so favorable to parts of the Southern States that Baron Mayor des Planches, the Italian Ambassador, has heartily indorsed an organized movement to turn Italians in that direction. I wish there were space to use the information concerning this most interesting enterprise which Baron Mayor has kindly placed at my disposal. 


\section{THE WHITE PERIL}

taining from negro tenants what are called "speculative profits," that is to say, interest on advances. The Italian tenant very soon saves enough to do without advances. Though the negro may be always in debt, he rarely fails, in the long run, to pay; and he is usually too poor a trader to get the best of a bargain - which the Italian frequently does. These considerations may for some time operate to keep the negro in the plantation system. But they will not suffice to keep the invaders out; for all over the South the demand for tenants and farm laborers outruns the supply.

This is, I know, but a scattering and incomplete arrayal of the observations which have convinced me that the large province the negro has always held in the industry of the Southern States is now being formidably invaded. I think, however, that enough has been given to show that his place in the South's industrial system can no longer be regarded as secure. Five years ago, Principal Washington declared that the next twenty years were going to be the most serious in the history of his race. "Within this period," he said, "it will be largely decided whether the negro 


\section{THE WHITE PERIL}

will be able to retain the hold which he now has upon the industries of the South, or whether his place will be filled by white people from a distance." The wisdom of the forecast is already proved; yet it neglected the native poor white.

All that I have said has been by way of showing that the negro has lost ground. But without his losing some ground no invasion could have occurred; and to say that it has occurred is not to say that he cannot resist it. Principal Washington is himself still undismayed. The apparent loss is, he holds, rather relative than absolute; it is largely explained by the South's rapid development and the gains of the whites in mere numbers. He is also cheered by the entrance of negroes into higher and higher employments, such as clerkships, stenography, and various branches of " business." My belief is, however, that it is nearly always mulattoes who rise in the industrial scale. It is probable, too, that the negroes have the same doubtful advantage that women have when they offer for the work of men. They will accept lower wages.

It is in trying to determine how much ground 


\section{THE WHITE PERIL}

the negro has lost that we turn most naturally to the statisticians. Unfortunately, the census-gatherers leave unasked many questions we should like to see answered; and some of the changes I have been describing are so recent that the returns of five years ago may have been but little affected by them. All that has been said of the townward movement among both races, and of the northward movement of the negroes is, however, sufficiently confirmed. But it is the tables dealing with occupations which seem most apposite. I shall not attempt to analyze them. It is safer to rest on the careful inferences of the experts. ${ }^{1}$ It should be explained that the term " negroes," as used in the returns, covers all races other than the white. For the South, however, the error involved in the failure to distinguish among colored peoples cannot be great.

In 1900 , more than two thirds of all the negroes engaged in remunerative occupations in the Southern States were in the three classes described

x The bulk of the Report is the work of Professor Walter F. Willcox, of Cornell University, doubtless the first authority in the country on statistics concerning negroes. Professor Dubois, of Atlanta University, in his chapter on "The Negro Farmer," is not less rigidly scientific. 


\section{THE WHITE PERIL}

as "laborers," "agricultural laborers," and "farmers, planters, and overseers." Within the decade, the number of negro "laborers" had increased by more than 60 per cent, the "agricultural laborers" by 22.3 per cent, the "farmers, planters, and overseers" by 3 I.I per cent. The increase in the first class does not look hopeful, but the boundary lines between the three classes are so vague and shifting that reasoning about them from the tables is discouraged. The same difficulty is found with certain other classes. There are also certain occupations, such as teaching and the Christian ministry, in which there is no appreciable competition between the races. In yet a third group, including such large classes as the hostlers, the masons, and the porters and helpers in stores, no figures by races for the Southern States alone were given in I 890. It appears, however, that in the case of at least fourteen leading occupations the figures for the two census years reveal the true course of an actual competition.

In five of those occupations, while both races gained, the negroes gained more rapidly than the whites. This was true of the class known as "ser- 


\section{THE WHITE PERIL}

vants and waiters," of the miners and quarrymen, of the nurses and midwives, of the iron and steel workers, and of the operatives in sawmills and planing-mills. In the other nine occupations, the negroes lost ground relatively to the whites. That is to say, the proportion of negroes among the draymen, truckmen, and teamsters in the South, among the steam-railroad employees, among the operatives in tobacco and cigar factories, among the fishermen and oystermen, among the engineers and firemen of other than locomotive engines, among the barbers and hairdressers, among the launderers and laundresses, among the seamstresses, and among the carpenters and joiners, was less in 1900 than it was in 1890 . In the two classes last named, there was an absolute decrease in the number of negroes. The figures for the whole country show also that there were fewer negro blacksmiths in 1900 than in 1890 ; and there is no reason to suppose that what was true of the whole country was not true of the Southern States.

The census tables, therefore, strengthen rather than weaken the inference from actual observation. So far as they throw any light at all on the 


\section{THE WHITE PERIL}

inquiry, they indicate that five years ago the negroes were losing rather than gaining ground in the industries of the South. It is disappointing that they do not yield more positive inferences concerning the great group of occupations covered by the general term "agriculture." We have, however, in the annual assessment lists of several Southern States which take account of the race to which each taxpayer belongs, some fairly safe material for an estimate of the negro's place in the greatest of Southern industries.

The Georgia assessments have been closely studied, and they seem to show that in the matter of acquiring land the negroes of that State are not now progressing as fast as they were at an earlier period of their history as freemen. In 1874 , the negroes of Georgia owned, all together, more than a third of a million acres. In seven years from that date, the amount was doubled. Ten years later, in I 89 I, the total passed a million acres. But at the end of the next decade there was practically no increase at all. The figures for the total wealth of the Georgia negroes, from year to year, parallel closely the figures for land alone. There is an in- 


\section{THE WHITE PERIL}

crease, gradual, but not constant, up to the early nineties; but for the next decade a slight positive decrease. However, it appears that the wealth of the white people of Georgia also declined in the nineties. It cannot be said, therefore, that negroes have been falling behind in the accumulation of property in general. But it is not clear that their failure to go on acquiring land is accounted for by the general shrinkage in values revealed by the assessments.

Moreover, they are in no position to be content with merely holding their own. Their own in Georgia is less than three per cent of all the land included in farms, and but little more than three per cent of the total wealth - and they are nearly half the population. True, they began only forty years ago, and with nothing. But the whites also were at that time woefully impoverished. Is it reasonable to suppose that the disparity would now be nearly so great as it is if the two races were of equal capacity for accumulation? If the disparity does not rapidly grow less, can it be contended that the negro is proving his case as a freeman, as an American? 


\section{THE WHITE PERIL}

For that, after all, in our commercial, industrial democracy, is the supreme test by which the negro's future on the American continent will be determined. The change which, if my observation is not egregiously at fault, is now coming over the industries of the South, is not merely an invasion of the negro's occupations. It is, rather, a change of standards of efficiency in work; and the negro's hope of rising, his chance of even holding his own, depends on his ability to live up to the new standard. With the increase of population, and a keener and keener struggle for wealth, the standard of industry, of skill, and of thrift will approximate more and more closely that of the Northern States and of the West of Europe. The white man whom the negro has to fear is no longer the man who would force him to work. It is the man who would take his work away from him. The danger, the immediate menace, is from rivalry rather than oppression.

But this is not to say that oppression, past and present, has nothing to do with the situation. The social and political status of the negro must certainly be considered. If it were different, his show- 


\section{THE WHITE PERIL}

ing in industry might also be different. Some, no doubt, will hold that the characteristics which handicap him most heavily in the struggle are those he got from slavery. That opinion, however, is not so common as it used to be. It is now freely conceded, even by leading negroes, that the training of slavery may have been as good a preparation for the race's present opportunities as any that this unregulated world of men could ever conceivably have vouchsafed it. The negroes of America were in this way immeasurably advanced beyond the competence of their fellows in Africa. Nine Southern employers out of ten will still declare that they prefer the laborer who has been a slave to the younger representatives of freedom. No doubt, an exception must be made of the graduates of schools like Hampton and Tuskegee. The testimony of those who know at first hand the work and the lives of these young men and young women is almost uniformly favorable. They are, however, but a little leaven in so great a mass. They cannot be treated as representatives, for, apart from their exceptional training, they may be said to have been, in a sense, selected. 


\section{THE WHITE PERIL}

But whatever we may decide about the effects of slavery, it is clear, I think, that the denials which they endure under the caste system work, on the whole, unfavorably to the negroes in the struggle for wealth. The sum of the matter seems to be that life does not offer to them the same inducements to endeavor which it offers to the white men about them. In the struggle for the things of this world, the negro is not lured on, as the white man is, by the visions of the kingdoms of this world, and the glory of them. It is a common and no doubt a correct observation that he is weak in the desire and purpose of self-betterment. But desire is generally in some degree proportioned to its objects, and purpose to its opportunities. Black men, I suppose, cannot help feeling that what they can win from life is always short of what they might win if they were white. I do not believe that the mass of them are agonized with the sense of denial quite as white men would be in their place. But may not the sting of it be keenest in those very men and women who, because they aspire most, must be counted on to do the most to lift up themselves and their fellows? The 


\section{THE WHITE PERIL}

caste arrangement which has succeeded slavery is of necessity, in some measure, deadening to ambition. On the other hand, it does not give the white man, as slavery did, the power, and the individually selfish motive, to make the negro work.

It has, no doubt, its compensations. There is sense in saying that to exclude the negro from politics was a good way to get him to work. He, like other human beings, probably works at times for the mere reason that there is nothing else in particular to do. It is also quite probably true that in his present stage he works best, as he fights best, under the eyes of those he looks to as superiors. Perhaps, from his low place in the social system, he exaggerates the happiness he would have in a higher, somewhat as the ignorant exaggerate the advantages of being learned. Possibly, if he were made in all things the white man's equal, he would lapse from those Caucasian ideals which attract him from above. But all these advantages of his being underneath, real as they may be, are, I think, more than offset by the practical uses white men may make of their superior station and their control over all branches of government. In the 


\section{THE WHITE PERIL}

courts of law, for instance, it is said that the property rights of the negro are protected quite as well as the white man's; but this is not true of his person, of his life. The negro assailant of a white man rarely escapes his punishment; the white assailant of the negro far too frequently does. Moreover, in all business dealings, selfishness is to be presumed. If white men, in their business dealings with negroes, never stoop to profit by their ascendancy through caste, then human nature has been sadly maligned.

It must, I think, be admitted that the competition is unequal. But it does not help the negro to dwell on the handicap he carries, whether from the past fact of slavery or the present fact of caste. Even if it should prove true that the heaviest handicap of all is his distinctly racial characteristics, entirely apart from his history in America, he might be no better off for admitting it. A wiser Godspeed is to tell him that his best chance, if not, indeed, his sole chance, of lifting himself, socially and politically, is precisely the chance he has of winning in the competition which is now being forced upon him. If he would strive for the 


\section{THE WHITE PERIL}

best place he can have in our American life, the way to it lies through work and saving.

The misery of all our debating about him is that we cannot honestly pretend to be glad that he is here, or to desire that his seed shall increase. Yet surely we can afford the honesty of telling him the truth. Let us tell him, at least, that it is idle to put his faith in party platforms or laws of Congress or amendments to the Constitution. Let us tell him that if he would have the white man's ballot or the white man's culture, if he would exact from white men, across the line of caste, fair dealing and considerate treatment, he must learn to match the white man's industry, his shrewdness, his forethought of the morrow. Were the admonition harsher, it would be more sincere. If he would keep the foothold he has now among us, if he would survive and live, and look to see his children live after him, he must put money in his purse.

1904. 
THE SOUTH AND THE SALOON 


\section{THE SOUTH AND THE SALOON}

$7 \mathrm{HE}$ South is perpetually interesting. So 1 much, at least, its severest critics concede. It used to be interesting because it was unlike the rest of the country, and insisted on remaining so. It is interesting still; academic and other students of institutions continue to discover and explore it, and seem to find readers for their reports. But the reason is different. Although still measurably peculiar, it now attracts the philosophically minded because it is changing. No other part of the country, in fact, presents to-day quite such a spectacle of transitions. Five or six years ago, traversing it from Virginia to Texas, I marveled that it had grown so unlike what it had been fifteen years earlier. Revisiting it now, I seem to find it departing even more widely from the state and ways in which $I$ found it then.

If, however, one looks a little more carefully into these changes, they cease to seem so surprisingly sudden. So much, in fact, is almost axiomatic 


\section{THE SOUTH AND THE SALOON}

concerning all civilizations. The apparent quiescence which precedes a striking événement in politics or social usage is usually only a surface calm, a mere stiffness of the crust, beneath which change has in fact been ceaseless; and this is particularly true of those alterations in the life of a community which accomplish themselves, and become overt, by sweeping legislation, swiftly enacted.

Within a year or two, the South has surprised the rest of the country with the culmination of two such processes. Several States have suddenly and violently asserted the right to regulate railroads. Three have as suddenly prohibited the traffic in intoxicating liquors. Perhaps Oklahoma, which has come into the Union with prohibition in her Constitution, is sufficiently Southern to be added to this list. The North Carolina Legislature, in special session, has submitted a prohibition statute to popular vote, in the full expectation that it will carry. In other States, a fervid and confessedly potent agitation looks to the same result.

Of course, neither of these two kinds of legis- 


\section{THE SOUTH AND THE SALOON}

lation is confined to the South. Northern and Western States also have tried them, and still try them. But that might once have almost seemed a reason why one should not expect to find them prevailing in the South at all. What now is most surprising, and food for philosophizing, is that the South is not only becoming like the rest of the country, but "more so." The facts suggest, and not altogether misleadingly, that some social force or forces, long potent elsewhere, but in the South atrophied or baffled, may now be at work there with the proverbial energy of things new or newly freed. It would not be a very bad generalization to say that the South has recently come into that phase of democracy in which government stretches its authority to the uttermost in the endeavor to enforce absolute moralities. Government is for the time being well-nigh puritanized.

This has come about elsewhere, and at other periods. But why should it come about "down South," and now? To explain that, we should have to go rather deep into Southern life. To explain it fully, we should also have to go rather 


\section{THE SOUTH AND THE SALOON}

far back in Southern history. If we should go deep enough and far enough, we should find, I think, that the South's present attitude toward the railroads and its uprising against the saloon are not entirely unconnected.

Of the earlier changes in Southern life since the war, none compares in importance with the political revolution of some twenty years ago, when politics ceased to be "qualitics" in South Carolina, and "Ben" Tillman succeeded a long line of aristocratic governors; when in State after State, - though less violently than in South Carolina, because in no other State had the old ruling class monopolized political power so jealously or set social standards so imperiously, - the "common" white man awoke to a sense of his power in the body politic. I call that particular change a revolution, and would use a stronger term if there were one; for no other political movement - not that of 1776 , nor that of I860-186Iever altered Southern life so profoundly.

It is true that the South never was such an aristocracy as too many writers about the slavery régime, tempted into picturesqueness, would 


\section{THE SOUTH AND THE SALOON}

have us think. Always, even in the "blackest" counties, in all the States, men who had little land and few slaves counted in politics. Many of the foremost public characters rose from that class. But neither the interests nor the ideals of the plain man dominated Southern civilization. Government for the most part responded to the demands of wealth invested in land and slaves, and the prevailing social tradition gave to birth, breeding, superiority, greater weight than they had elsewhere in America. Cities being few, it was near the outbreak of the Civil War before a commercial class developed which could challenge that tradition.

Nor did the plain white man come into his birthright at once on the fall of slavery. For a generation or more, the impoverishment of the whole region operated to withold from him the opportunities which slavery had so long denied. His real enfranchisement came only with the gradual dawn of prosperity, and the accompanying changes in the South's industries. Those changes have brought him much the same chance in life which he has in the North. And 


\section{THE SOUTH AND THE SALOON}

with that there has come to him the new sense of independence and power.

In politics, as he quickly discovered, the sense of power was all he needed in order to possess the reality. More gradually, and not even yet completely, he has come into his own in all those subtler ways in which democratic usages and ideals supplant the aristocratic. The disfranchisement of the blacks has in this respect hastened the process begun by their emancipation. It has weakened the prestige of the old slave-owning class, of the men who, living in those quarters where negroes are most numerous, not only represented them, so long as they voted or were supposed to vote, in legislatures and democratic conventions, but could usually, by appealing to the fear of negro domination, dictate party policies. The negro eliminated, majority rule seems now to prevail as generally among Southern whites as in the North. And in the South, as in the North, the great majority of the majority are plain or "common" men.

But not quite the same kind of "common" men as in the North; else history were negligi- 


\section{THE SOUTH AND THE SALOON}

ble. For one difference, the plain man in the South seems to feel a rather deeper distrust of capital, a rather angrier hostility to every privilege of wealth, than one finds in the plain man of the North who is not a socialist or aggressively a "workingman." Were we to follow that lead, and consider carefully the industrial past and the economic outlook of the plain Southerner, we should, I think, discover why Southern legislatures have been dealing so drastically with the railroads. But for the moment what challenges inquiry is the South's fierce awakening to an old moral issue, and one naturally turns, therefore, to the moral training and standards of the now dominant class.

The word "class" is usually misleading in America. One must employ it cautiously. By the plain or "common" men of the South I do not mean a sort of people that can be clearly separated from the rest. I do not mean the vaguely imagined class which is usually called "poor whites" in books about the South by writers who do not live there. Those pathetically backward dwellers in the mountain regions are still a comparatively 


\section{THE SOUTH AND THE SALOON}

negligible factor, save as they have come down, attracted by the town and the factory, and joined the greater mass that is both poor and white, but without inverted commas. The really common sort of common people have always dwelt in the lowlands and the Piedmont region. We need not distinguish between the small farmers, on the one hand, and the artisans and small shopkeepers of the towns, on the other. It is enough if we merely exclude all who have a tradition of wealth and of political and social ascendancy before the war. That means excluding the very attractive people of Mr. Thomas Nelson Page's stories. It means excluding, I fear, all such people as the Southerners one meets in the North lead one to believe that they and theirs have always been.

Now, in the class which we thus deliberately neglect as a no longer controlling minority, the Episcopal Church hasalways had its main strength in the South. The Southerner of "quality" is usually of that religious fold. When he is not, he is most likely Scotch-Irish and Presbyterian. In South Carolina he might be a French Huguenot; in Louisiana and Maryland, a Roman Catholic. 


\section{THE SOUTH AND THE SALOON}

The far greater mass of plain people to whom we turn are nearly all Methodists or Baptists.

They take their moral and religious guidance, therefore, from a ministry whose methods and whose power constitute an important neglected fact of Southern life. In both these denominations, the proportion of college-bred or otherwise cultivated men and women is comparatively small. Both inculcate a strict and narrow adherence to the scriptural code of morals. Both, for instance, frown upon dancing and amateur theatricals. Neither requires its ministers to be educated. In both, the preaching is for the most part highly emotional. Both are given to revivals.

Mr. Walter H. Page and other progressive Southerners have spoken bitterly of the Southern pulpit as an influence constantly operating to arrest intellectual development; and that is not the only ground on which the Methodist and Baptist preachers in particular are open to criticism. But on the score of zeal, industry, devotion, these men need not fear comparison with any priesthood in the world. None too well equipped intellectually, and deriving no aid from any superiority in birth 


\section{THE SOUTH AND THE SALOON}

or breeding or culture to the people whom they serve, they are also generally ill-paid. Many of them must maintain families on salaries of four or five hundred dollars a year. Yet they rarely incur a charge of loitering in the vineyard. They preach incessantly; they make daily rounds of visits to the homes of their communicants; they act as unpaid canvassers for their denominational schools and colleges; they keep in touch with one another, and study their people as closely as the most observant politician; they do not neglect the ever-widening influence of women. So great is the power which they thus collectively exercise that if one were to call the plain people of the South "priest-ridden," the strongest objection to the phrase would be, that the Methodist and Baptist ministers do not consider themselves priests.

It is these men in the South who have taken the lead in the now almost world-wide movement for prohibition. Episcopal clergymen hardly ever take an active part in the movement; not infrequently, they actually oppose it, as not a wise or proper method to promote temperance. The Catholic clergy, not a great power in the South 


\section{THE SOUTH AND THE SALOON}

outside of a few large cities, take the same general attitude. Presbyterian ministers, although they may favor prohibition, rarely feel free to advocate it from the pulpit. But the Baptist and Methodist preachers commit themselves to it unreservedly, inside and outside the pulpit. They are for prohibition by local option as against high license and dispensaries, but for State prohibition as against local option. Temperance they have virtually ceased to preach, demanding instead that Government compel all men to become teetotalers.

And it is their congregations which supply the readiest converts to this policy. To the small farmer or shopkeeper or artisan of the South, the drink habit presents itself in its crudest, least defensible form. Among people of this class, the custom of taking wine with food is virtually unknown. Of wines, in fact, the common people of the South know so little that they use the word "wine" as if there were only one kind of wine in the world. Beer, while of course a not uncommon beverage in the cities, does not find its way into the country. Accordingly, to drink means ordinarily to drink whiskey, and not at table or 


\section{THE SOUTH AND THE SALOON}

in the restraining company of women, but in surroundings the least conducive to moderation and decency. It means, therefore, deplorably often, not merely drunkenness, but rowdyism. The greed of the liquor-dealers and the brewers behind them, and their amazing contempt of public sentiment, have contributed to render the drinking habits of the South as unlike as possible to those of southern Europe, where wine-drinking is general, even among the peasants, and drunkenness extremely rare. Nowhere does the prohibitionist agitator, with his terrifying figures and highly charged oratory, find a better opening.

Once the Democratic party, dominant everywhere in the South, had committed itself to local option, prohibition made rapid gains in the rural counties and the smaller towns. Two years ago, when the movement for State prohibition won its first victory (in Georgia), the greater part of the South was already under prohibition laws. A year ago, the leader in the local-option movement in North Carolina ${ }^{x}$ pointed out that nine tenths of

1 Mr. J. W. Bailey, of Raleigh, President of the North Carolina Anti-Saloon League, 1903-07. 


\section{THE SOUTH AND THE SALOON}

the people of that State were living in prohibition territory, and that there were within its limits only one fifth as many open saloons as in Kansas, which has had State prohibition for a quarter of a century.

The same authority also declares that the South, having turned from the local-option plan to State prohibition, is now " in full cry on the coldest trail in its history." That is an opinion which gets much support from the report, ably summarized by President Eliot, of the sub-committee on legislation appointed by the Committee of Fifty, which, several years ago, secured for us the most authoritative data we have on the liquor problem. But the men and women now fighting the saloon in the South do not make use of such material as the Committee supplies. In a city where, after an absorbing campaign, prohibition recently won, the copy of "The Liquor Problem" in the public library - quite probably the only copy in town - does not seem to have been consulted at all. The chairman of the "dry" committee had not even heard of the Prohibition Year-Book. The fight was won, in fact, mainly by the devices of a Meth- 


\section{THE SOUTH AND THE SALOON}

odist revival or "protracted meeting " : by terrifying and rather coarsely emotional oratory from pulpit and platform, interspersed with singing and praying; by parades of women and children, drilled for the purpose; by a sort of persecution, not stopping short of an actual boycott, of prominent citizens inclined to vote "wet"; by the Anti-Saloon League's very effective short method with politicians, whom it convinces that they have more to lose by offending the league than by deserting the saloon-keepers; and finally, by fairly mobbing the polls with women and children, singing, praying, and doing everything conceivable to embarrass and frighten every voter who appeared without a white ribbon in his lapel.

It is these methods, gradually perfected in campaign after campaign, that have won for prohibition so many victories in the towns and counties. It is the politicians' absolute helplessness against such methods, and the success of the Anti-Saloon League in its determination to teach them that "the most dangerous thing for a politician to tamper with is the saloon vote," which has suddenly won over to State prohibition legislatures 


\section{THE SOUTH AND THE SALOON}

full of men who never before gave any help to the temperance cause.

And it is the dislike of such methods, however moral the cause, which must inspire in thoughtful, unexcited minds a grave distrust of the permanence of the good results of the movement. The depth and sincerity of the present feeling against the saloon are beyond question. There is in it a moral and religious fervor which reminds one of the way the Piagnoni - the white-ribboners of Savonarola's time in Florence - drove vice and even vanity out of the city by the Arno; of the Puritan revolution in England; of countless lesser social purifications. But one cannot recall the achievement of the Piagnoni, as George Eliot has portrayed it in " Romola," without recalling also the reaction that followed - Dolfo Spini and his brutal Compagnacci, Savonarola in the flames, the Medici returned. One cannot think of Puritan England without remembering also the England of the Restoration - the profligate king and brazen court, the playhouses, which had been closed to Shakespeare, reopened to the indecencies of Wycherley and Etherege, the shameful tribute to 


\section{THE SOUTH AND THE SALOON}

France, the persecuted Milton. One is moved to question whether any moral cause is ever permanently advanced otherwise than by fair appeals to a deliberate public opinion and an uninflamed public conscience.

But to admit that reactions always follow violent gains, that a penalty is always paid for bigotry and intemperate zeal - is not this merely to admit that moral progress is wave-like? As civilization advances, the reactions may well be less and less in proportion to the gains. Moreover, unless long study of Southern history has utterly misled me, it has always been a mistake to infer fickleness, instability of purpose, from the Southern people's almost Latin responsiveness to emotional appeals. On the contrary, they have often displayed an extraordinary steadfastness in courses hastily entered upon. No doubt it is too much to expect that prohibition will hold all the ground it has won and may yet win in the South, or that prohibition laws will not, there as elsewhere, often fail of enforcement. But the saloon can never be again in the South what it has been in the past. That the politicians will ever again serve it as they 


\section{THE SOUTH AND THE SALOON}

once did is not believable. They have been too thoroughly, too ludicrously frightened. One may even hope that in the long run the open saloon is bound to go entirely; that with the opening-up of the South to all kinds of education and softening and refining influences, the indefensible drinking customs of most Southerners - as of most Americans, indeed - will gradually be changed; and that thus, without any countervailing sacrifice of moral independence or personal liberty, drunkenness will grow rare enough to be well-nigh negligible.

That is a great deal to hope. But there is one feature of this temperance movement peculiarly conducive to hopefulness for Southern civilization. I cannot better indicate what that feature is than by pointing out that I have hardly mentioned the negro at all. It is quite probable that his presence in the South has influenced some white voters. It has doubtless been remembered that in race riots whiskey usually plays a part. But this argument has not in fact been generally employed. On the temperance question, no race line has been drawn. Whites and blacks have di- 


\section{THE SOUTH AND THE SALOON}

vided on it with little or no reference to its bearing on their racial relations. For once, it would seem as if the South had actually been able to put aside the race issue altogether. One is tempted to declare that, if it can do that, it can do anything. 1908. 
PRESIDENT TAFT'S OPPORTUNITY 


$$
\text { - }
$$




\section{PRESIDENT TAFT'S OPPORTUNITY}

STRONG President's power of initiative in 1 his own party is very great. It was the will of Cleveland that committed the Democrats to tariff reform as their main proposal in the campaign of 1888 . In 1896 , it is true, Cleveland failed to hold his party against the free-silver craze; but he made the outcome doubtful for months, notwithstanding that his leadership wasalready greatly weakened, and that the heresy, as is now apparent, had infected an overwhelming majority of the party throughout the country. Had McKinley lived, and remained steadfast in the position he took in his last public speech, the chances are that years ago we should have had some kind of revision of the tariff by the Republicans. President Roosevelt, on the other hand, devoting himself to the task of keeping within bounds the corporations and trusts, brought his party to an at least normal concurrence in his views. 


\section{PRESIDENT TAFT'S OPPORTUNITY}

The Republican party has greater coherency than the Democratic. A Republican President has, therefore, a greater power of initiative in his party than the Democratic President has in his. The present state of both parties gives to President Taft an opportunity to exercise this power to extraordinary ends. If he has the will and the skill, it seems probable that he may alter the composition of both; and that he may also alter their geographical alignment. To make this plain, it is necessary to go inside the lines of both, and examine the actual groupings of voters as they have been revealed by the several elections since the first nomination of Mr. Bryan in 1896 .

That nomination, of course, marked the triumph of the radicals in the Democratic party. It also opened the door to the Populists, the mass of whom have since entered, or reëntered, the Democratic ranks. With this great reinforcement, the radicals seem to be still clearly in the majority. Their greatest strength is in the West, and they have the upper hand in the South. In certain of the Eastern States also the element most in sympathy with them has got control of the party ma- 


\section{PRESIDENT TAFT'S OPPORTUNITY}

chinery. But this element, made up largely of the foreign-born, and strongest in the cities, does not fuse readily or completely with the radical faction of the West and South, which is, so to speak, country-bred; which is in fact the counterpart in all essentials of Jefferson's following and of Andrew Jackson's. What specific policies it stands for to-day is not of the first importance. In general, it stands for opposition to privilege, particularly the privilege of wealth, and it readily accepts crude devices to equalize opportunity. But Americans of this class have sincere reverences, and passionately associate venerated names with every new proposal they make. It is no injustice to call certain of their proposals a menace to free government; yet it is no more than justice to recognize the spirit behind those proposals as the true militant spirit of American democracy. That concession enables us to see also wherein this home-bred and rural radicalism differs from that of the East, or, to be more accurate, from that of the cities. The spirit of the latter is in fact the spirit of European democracy. Between the two wings of the radical faction there is thus, as there was between 


\section{PRESIDENT TAFT'S OPPORTUNITY}

Jefferson's ideas and those of the French Revolution, more kinship than identity. But conditions of life throughout the Republic grow constantly more uniform; the local and peculiar yields to the general. Every year America comes into closer and closer touch with "abroad"; the national yields to the cosmopolitan, the universal. Discontents and aspirations concerning the social order in America will, therefore, we may feel sure, tend to ally themselves with like discontents and aspirations in older lands, and become more and more frankly socialistic. The best reason given for supporting Bryan last autumn was that his election would put off the day when a really formidable socialist party shall throw down its challenge to whichever of our two historical parties may still survive.

That argument prevailed, no doubt, with some members of the other great Democratic faction, whom it is the fashion to call "conservatives," but whom, as our party system grows more like that of Europe, we would perhaps better call " moderates." What the Rockingham Whigs were in English politics at the time of the American Rev- 


\section{PRESIDENT TAFT'S OPPORTUNITY}

olution, these men are in our political life to-day.

No other political group has so large a proportion of men of light and leading; no other holds so steadfastly to definite principles, or to principles which history and reason so well approve: yet no other, seemingly, has so little chance to come into power. Unable either to countenance the dangerous vagaries of the radicals now in control of their own party or to shut their eyes to what they regard as the long subservience of the Republican party to privilege, they have nevertheless learned from their experience in 1896 that it is useless to set up a party establishment of their own. In 1904, when the Democratic convention named a candidate they could accept, hundreds of thousands of Bryan's more devoted followers fell away from him and left him to mortifying defeat. While the radicals control, the moderates are thus thrown into a hesitation which is fast becoming their chronic state. Some, still clinging to the hope of bringing the party back to sound policies, keep themselves "regular" as best they can; some have become Republicans; the greater number, though believers in party, find themselves 


\section{PRESIDENT TAFT'S OPPORTUNITY}

forced into the attitude of independents. With the true independents, they hold the balance of power in many States. This fact came out at the last election more strikingly than ever before. In twenty-four of the thirty States which elected governors last November, the Democratic candidates ran ahead of Bryan, some of them by many thousands. The aggregate vote for his party's candidates for governor in those thirty States exceeded his vote in the same States by nearly half a million. The figures also illustrate the Democratic dilemma. Outside of the Southern and two or three of the newer Western States, the dominant radicals can hope to win only by putting forward, and themselves supporting, candidates acceptable to the moderates. The moderates, on the other hand, even if they should regain control, could not reasonably expect to win outside of the South except, possibly, in a few States of the East where they are strongest. Under Cleveland, the Democratic party made great gains in New England. In I 890, an actual majority of the Congressmen elected in New England were Democrats. Were the party again united under a leadership like 


\section{PRESIDENT TAFT'S OPPORTUNITY}

Cleveland's, and were the tariff the issue, Massachusetts would to-day be a doubtful State. But Cleveland is gone, and the young William E. Russell, whom the auguries of happier years had seemed to proclaim his successor, went before him to the grave. Under its present leadership, barring almost inconceivable Republican follies or sins, the party can look for nothing in the East but sporadic local triumphs, won on local issues. Its sole and none too robust hope must remain what it was in the recent campaign: to keep the South for a base, and make gains in the West.

Its chances in the West would be better if, in the recent contests of the two great Republican factions, fortune had favored the losing side. I will use the terms "conservative" and "progressive" to designate these two factions, as best corresponding to the terms "moderate" and "radicals," which I have applied to the Democratic factions. The division among the Republicans is, no doubt, somewhat less clearly marked than that among the Democrats, but it is not less real, and for the time being it is more important. It is roughly com- 


\section{PRESIDENT TAFT'S OPPORTUNITY}

parable with the division of the English Conservative party into Tories and Unionists.

The conservative Republicans stand for the rights of property - perhaps it would not be unfair to say, for wealth - with a singleness of purpose and animus hardly to be matched by the most conservative group in any one of the party systems of older countries; for we have neither an established church nor an aristocracy of blood to inspire another kind of conservatism. Like the moderate Democrats, they are strongest in the East, but they are almost equally strong in the older States of the West - the two quarters, it should be observed, where the party also is strongest.

The progressive Republicans, on the other hand, are strongest in that farther West, which, through the ascendancy of the radicals in the Democratic party, has become, with certain of the Border States - Maryland, Delaware, and Kentucky the true battle-ground in national contests. Of the four old "pivotal" States, three - Connecticut, New York, and New Jersey - are under present conditions safely Republican; only the fourth, Indiana, remains at all doubtful. The creed of 


\section{PRESIDENT TAFT'S OPPORTUNITY}

the progressives is nowhere fully and clearly formulated; but they stand for a strong reaction against that complacency with private and corporate greed into which the party fell so soon after the Civil War. Like the Democratic radicals, they have felt, and still feel, the impulse of Populism; they have many former Populists in their ranks. Some of their leaders, such as Cummins and La Follette, seem really to have more in common with Bryan than with Republicans like Aldrich and Cannon. Their two most distinctive departures from the once orthodox Republican attitude are their demands for firmer control and closer regulation of corporations and for a more liberal tariff policy.

Notwithstanding President Roosevelt's avoidance of the tariff issue, he made himself the leader of the progressive faction; and he made it the dominant faction. We can hardly question any longer the immediate political expediency of his course. To his astuteness, hardly less than to the folly of the Democrats and the incompetence of their present leaders, his party owes the new grant of power which it has won, contrary to all pre- 


\section{PRESIDENT TAFT'S OPPORTUNITY}

cedents, in the midst of an industrial depression following a financial panic. I will not say that President Roosevelt should not have credit for something better than mere astuteness. His silence on the tariff, particularly in view of McKinley's remarkable last speech at Buffalo, is hard to condone; but his insistent demand that the great combinations of capital shall obey the laws, violently as he sometimes made it, crude as were some of his specific proposals, was not merely popular, it was right. Had he, on the other hand, allied himself with the conservatives, and ignored the outcry against the abuses of corporate power, his party would no doubt have had a heartier support both from ultra-conservative Republicans and from the most conservative element among the moderate Democrats ; but he would have driven thousands of progressive Republicans, particularly in the doubtful States of the West, out of the party, and he would have made it well-nigh impossible for moderate Democrats to come into it.

The victory to which he led the progressives was, however, by no means complete. Cannon is still Speaker, Aldrich still leader of the Senate, 


\section{PRESIDENT TAFT'S OPPORTUNITY}

Sherman is Vice-President. It is idle to fancy that the great interests against which the progressives have made war will not always have strong representation in public life. The new Administration faces the same four - or, if we count the independents, the same five - political groups with which its predecessor had to deal.

Should President Taft turn to mere compromise and conciliation, he may leave them much as they are. Should he prove, notwithstanding the earlier portents, at heart a reactionary, and the conservatives, strengthened by his favor, come into their old ascendancy, the opposition will win recruits among the progressive Republicans, the moderate Democrats will again waver back toward their old party standard, and many independents will go with them. A fresh Democratic opportunity will be created, and perhaps, after so long chastening, the party will be wise enough, by turning to old tenets and new leaders, to seize it. Should the Republican reaction go far enough, it might even bring victory within reach of the opposition as it is.

The third course open to the Administration 


\section{PRESIDENT TAFT'S OPPORTUNITY}

is that which all signs have indicated that the President is minded to take. If he continues to insist, less violently than President Roosevelt, but not less firmly, that the corporations and " combinations of corporations" shall obey the laws, and goes on carefully perfecting the laws which aim to control them, he will hold the progressives of his own party; and if, in addition, he proves sincere and determined, and carries his party with him, in the effort to squeeze the sheer robbery out of the tariff schedules, even though the protection, properly so-called, remains, he will win over many moderate Democrats, and he will commend himself to the independents. Of course, he will not please the conservatives - the Aldrich-Cannon Republicans. They will fight such a policy ceaselessly and resourcefully, and the great interests they represent will support them. But they will fight inside the party lines; if defeated, there is no other party to which they can turn. In this way, granting ultimate victory to the progressives, they may become, in the actual working of the Government at Washington, a sort of Center, with conservatives of their own 


\section{PRESIDENT TAFT'S OPPORTUNITY}

party constituting the Right, and the Democrats, under radical control, the Left.

But in this forecast I have purposely omitted to consider a factor which, at present, makes against it-which, indeed, makes against any conformity of our political life to the normal usage and development of representative governments. Radical democracy in America draws its inspiration from the West, but the base and stronghold of the Democratic party, whether its policy is radical or moderate, is still not the West, but the South. If, therefore, I have thought that the present Administration may alter the composition of our parties, it is partly because I have thought that it may also alter their geographical alignment: because it may, if it will, bring us to the end - at any rate, to the beginning of the end of the South's political solidarity.

This is no new hope. On the contrary, it has been so often entertained, and so often disappointed, that one must give better reasons for entertaining it again than the mere fact of $\mathrm{Re}$ publican gains in the Border States. From 1892 to 1908 , the figures do show a marked progress 


\section{PRESIDENT TAFT'S OPPORTUNITY}

of the Republicans southward. West Virginia became first occasionally and then steadily Republican. Maryland, Kentucky, and Missouri have all gone Republican in certain elections, and must now be accounted doubtful. But the industrial development of West Virginia has so changed its population that it is no longer a Southern State. Nor can the other three stand for Southern conditions. In 1904, when Missouri went Republican, and Kentucky and Maryland divided their electoral votes, Mississippi increased her Democratic majority. We cannot attribute to this political change of heart in the Border States quite the same significance it would have in any one of the old Confederate States. It may well be argued that in the former the interests which they share with the North have simply outweighed those that they share with the South. But were Alabama and Georgia to go Republican, we should feel that the white people of those States had made up their minds that they can vote a Republican ticket without endangering that to preserve which they have so long denied themselves the privilege of full political independence. 


\section{PRESIDENT TAFT'S OPPORTUNITY}

The figures of the election last autumn in the distinctively Southern States are thus far more significant than those of recent elections in the Border States. They showed an increased Republican vote in every one of the eleven States of the Confederacy, the gains varying from a few hundreds in Mississippi and South Carolina, where virtually no Republican party existed, to more than 1 3,000 in Tennessee, more than 16,000 in Georgia, and nearly 34,000 in North Carolina; this last being decidedly the greatest gain, absolutely as well as relatively, that the party made in any State of the Union.

The figures are really much more significant than they seem. In none of these States do more than a few thousand negroes go to the polls. As the Democratic primaries have long constituted the real elections, great numbers of whites also neglect to go to the polls on election days. These gains were made, therefore, in a total vote far less than would have been cast by the same population in the North; and they are gains of white votes. Probably fewer negroes voted for Taft in 1908 than for Roosevelt in I 904 . Some, mindful 


\section{PRESIDENT TAFT'S OPPORTUNITY}

of Brownsville, voted against him. Of the I I4,oo० Republican votes cast in North Carolina, certainly more than 100,000 were cast by white men. Although the National Committee refused to appropriate a cent to that State, a change of less than 12,000 votes would have given it to Taft. A change of 9000 votes would have given him Tennessee. In Arkansas and Georgia, also, the Republicans not only increased their own vote, but cut deep into the Democratic majorities.

Clearly, it would seem, these States are open to Republican invasion. How can the Republicans best invade them? We can approach an answer by seeking the causes of the change already come about.

There have already occurred, since the Southern people regained control of their own affairs, two secessions from the Democratic party in the South. First came the Farmers' Alliance-Populist movement, in the late eighties. An outcome of hard times, and Western in its origin, that movement took in the South the form of a rebellion against the aristocratic element which had ruled before the Civil War, and which, with the 


\section{PRESIDENT TAFT'S OPPORTUNITY}

undoing of Reconstruction, had again come into power. It was also a sign of growing discontent with the methods used to keep the mass of the negroes, not then legally disfranchised, from voting. It came suddenly, and quickly developed a dangerous strength. Reuben F. Kolb, the Populist candidate for governor of Alabama in 1890 , was not improbably elected, though never seated. In North Carolina, a fusion of Populists and Republicans won in 1894 and 1896 , and sent J. C. Pritchard and Marion Butler to the Senate. Except in South Carolina, where Tillman and his following had at the start captured the Democratic organization, alliances of Republicans and Populists prevailed throughout the South until I 896, when the Democrats cameout for free silver and the Republicans for the gold standard. After that year, the Democratic party in the South, as elsewhere, gradually reabsorbed the Populists by adopting most of their platform.

But this caused a second secession, that of the moderates, the Cleveland men, who would not support Bryan and free silver. These men returned to the party in 1904 . That was one reason 


\section{PRESIDENT TAFT'S OPPORTUNITY}

why Roosevelt did not make a better showing in the South. But with Bryan again leading the Democrats, and a progressive leading the Republicans, they have again, and in far larger numbers, asserted their independence. To the discontent with the Democratic candidate and platform there is now added a growing disgust with the party itself, which is regarded as unfit for power, and a growing hope in the Republican party.

It is, of course, essential, if the South is to give up its solidarity, that the Republican party shall commend itself to a majority of the voters in some Southern State or States. It cannot ask Southern men to vote for policies they disapprove merely because it is desirable to have a live Republican party in the South, nor even because, by turning Republican, they can win for the South a stronger voice in all national affairs. It cannot ask them to do more than vote as they believe. But as a matter of fact, while the progressive faction controls the Republican party, and the radical faction the Democratic, the drift of Southern opinion is clearly and strongly Republican. This drift was arrested in 1904 by the nomination of Parker and 


\section{PRESIDENT TAFT'S OPPORTUNITY}

by the feeling against President Roosevelt because he had had Principal Washington to dinner, had appointed Crum Collector at Charleston, and had closed the post-office at Indianola. It would probably be again arrested if either the moderates should regain control in the Democratic party or the conservatives in the Republican. Were both these things to happen, the tide would doubtless turn the other way. If, however, present tendencies shall continue to prevail in both parties, it is only a question of time when in more than one Southern State those who in their hearts favor the Republican party will be - if, indeed, they are not already - the majority. But that, unfortunately, is not enough. It is not enough that Southerners should change their faith; they must be persuaded that it is safe for them to vote as they believe.

There is no better way to persuade them that it is safe - I doubt, indeed, if there is any other way - than to make it safe. I believe that the wisest course now open to the Republican party - and the right course - is to consent, candidly and unequivocally, that it shall be safe. 


\section{PRESIDENT TAFT'S OPPORTUNITY}

That it has substantially so consented, ever since the last Force Bill was killed, is what has made possible its recent gains. These became possible, not in spite of the laws which operate to disfranchise the mass of the negroes, but because of those laws, and because the Republicans had virtually accepted them. President Roosevelt had accepted them in a published letter, declaring that no one of consequence seriously considers punishing the South for passing them so long as they are fairly enforced. The Supreme Court had refused to declare them unconstitutional. Congress had acquiesced by inaction.

This attitude of the three departments of the Government, all three being in the hands of the Republicans, has encouraged many Southern voters to disregard mere platform demands and threats. But there are still many other Southerners who feel differently; and the insincerity is in itself a thing to reprobate, not to condone. The time has come for plain speaking on this whole subject. The Southern people will not consent that their suffrage laws shall be dictated, directly or indirectly, from without; and I believe the 


\section{PRESIDENT TAFT'S OPPORTUNITY}

best Northern opinion also to be that interference from without works more harm than good. If it did not succeed when the Southern people were beaten, impoverished, apparently helpless, is it likely to succeed now, when they are erect, prosperous, in full control of their own affairs? Fortytwo years ago, overriding President Johnson, and disregarding the policy of Lincoln, Congress did all that could be done to force the negroes into the electorates of the Southern States. For ten horrible years the National Government bent its vast strength to the task of keeping them there. Yet to-day there is nothing gained beyond the proposal of Lincoln in I 864, in his well-known letter to Governor Hahn of Louisiana: "I barely suggest for your private consideration whether some of the colored people may not be let in as, for instance, the very intelligent, and especially those who have fought gallantly in our ranks." One of the few things which seem to be certain about the race problem is that the rest of the country cannot control, however it may disturb, the political relations of the two races in the South. 


\section{PRESIDENT TAFT'S OPPORTUNITY}

Should the Republican party again attempt what it cannot hope to accomplish, it would merely drive the Southern white voters back into the solidarity they seem ready to abandon. If it continues to threaten in platforms what it does not mean to attempt, it will probably mislead many of both races, to the good of neither, and may in the end disgust both. By honesty and candor, it can permit the stronger, and may perhaps lead the enfranchised members of the weaker also, to divide freely, like other Americans, according to their convictions, at the polls. Since whatever of the substance of political power black men now have in the South they have by the consent of the Southern white men, they would lose little by the change; and there remains the untried hope of their wisest leader that they may gain from the unforced sense of justice of the white race what its stubborn strength would never yield to compulsion.

But there is more for the Republican party to do, if it would rise to its opportunity in the South, than merely to cease from this insincerity. It is not enough merely to induce Southern white men 


\section{PRESIDENT TAFT'S OPPORTUNITY}

to vote Republican in national elections. When they do that, they are debarred, not only by party law but by a public opinion which on this point is peculiarly strong in the South, from the Democratic primaries. Yet in too many Southern States mere self-respect has hither to been enough to keep such men out of the organizations which represent the Republican party. These must simply be reconstituted before Southern white men of the class which the party has the best chance of winning will consent to join it.

Here is perhaps the most difficult practical aspect of the situation; and here the task which most clearly devolves upon the President in his capacity of party leader. The power long possessed by small groups of office-brokers and vendors of delegates in national conventions must be put into better hands, and the organization made, as the phrase is, "respectable." The new recruits, drawn largely from the higher walks of Southern life, and the men who have been Republicans in years when the term carried reproach, must be brought into some kind of fellowship. Offices and honors must be fairly distributed. Were there no 


\section{PRESIDENT TAFT'S OPPORTUNITY}

Federal offices to distribute, the transformation, as Mr. Taft himself once suggested, might be easier. For the transformation will not be accomplished until victory at the polls, not recognition from Washington, shall become the goal of party activity.

To President Roosevelt, notwithstanding what I cannot help thinking the serious and costly mistakes in his Southern policy, we must give credit for blazing the way for this enterprise of revitalizing his party in the South. ${ }^{x}$ Before he went into office, he had discussed the situation with Southerners of the bešt class, and had come to feel that Southern people had a real grievance in the unrepresentative character - and none too seldom the bad character - of holders of Federal offices in the South. He accordingly made up his mind to appoint Democrats freely where he could not get good Republicans. This he repeatedly did, to

I I wish to make this acknowledgment the more pointed because I am satisfied that in an article published during the campaign of 1908 , having been somewhat misled by a certain published statement about the socalled "referee system," and by the strong feeling of certain Southern Republicans against that system, and the article itself having been written under peculiar circumstances which denied me all opportunity to verify or correct it, I did President Roosevelt some injustice in this regard. 


\section{PRESIDENT TAFT'S OPPORTUNITY}

the improvement of the public service; and by this policy he fostered a friendlier feeling toward his party. Another resolve he made was to appoint comparatively few negroes to office, and those, if possible, of the better class; and this also was wise. Unfortunately, however, he chose Charleston of all places - for one such appointment to a conspicuous office ; and this, with his "door of hope" letter, and the other incidents I have mentioned, exasperated the whites, aroused wild expectations among the negroes, provoked an outburst of race feeling, and deprived him, for a time, of the liking of the Southern people, whom he had at first much attracted.

His policy required him to disregard the advice of his party's committees in the South when he felt that he could not trust them to name good men; yet recommendations from some source he must have. He accordingly had recourse to the much-discussed "referees." He did not, as has been commonly supposed, invent the "referee system" of appointments. More than one of his predecessors, in making appointments in States that had no Senators or Representatives of the 


\section{PRESIDENT TAFT'S OPPORTUNITY}

President's party, had resorted to advisers of their own choosing. Mark Hanna, in nominating McKinley, had built up a "machine" in the South, and the heads of this had become, under McKinley, the "referees" concerning appointments in their several States. To these men President Roosevelt also turned, and he continued the practice, although in some instances he changed the referees themselves. In Mississippi, he made a Democrat the referee; in many other instances he consulted Democrats about appointments. All this made, on the whole, for better appointments; but it had other results not so acceptable. It might have been foreseen, one would think, that to the keen-scented hunger of office-seekers the true sources of presidential favor would not remain long hidden. It did not, for instance, long remain hidden that a Democrat appointed to the Federal bench in Alabama owed his appointment to Principal Washington, or that the same adviser had actually named the referee for Mississippi ; and the effect on Southern public opinion was not good. The referees found it easy, when they so desired, to make themselves the masters of the Republi- 


\section{PRESIDENT TAFT'S OPPORTUNITY}

can organizations in their respective States; for these turned to whatever power dispensed the offices, as a sunflower turns to the sun. It has even been charged that in Mississippi the referee used his power - as he could, since many of the appointments made on his recommendation were of Democrats - to aid in a contest for control of the Democratic party. $\mathrm{He}$ is also blamed for the unsatisfactory outcome of the Indianola incident, because of the advice he gave the President. In general, since the referees were responsible only to the President, their setting up, however good the motive, and however the device may have improved the character of appointments, certainly did not give to the Republican party the vitality and independence which it so sadly lacked. President Roosevelt abandoned the system some time before he went out of office. It is quite possible that the standard of appointments to Federal offices will somewhat decline if the party committees are left to make the recommendations; but in the end the South will be the gainer if the change shall prove a sign of the coming to life of the party behind the committees. 


\section{PRESIDENT TAFT'S OPPORTUNITY}

But the Administration, if it would contribute all it can to this consummation, must go further still. It must see to it that the men at the head of the Southern machines shall realize that their old occupation - the getting together of pliable delegations to Republican national conventions - is gone forever. So long as this practice continues, there will exist, for the leaders of the party in the South, whether referees or committeemen, and for the Northern managers in closest touch with them also, a motive to keep things as they have been.

Here, it may be thought, is too much said of the South in a survey of the entire national field. But those who know the true history of the Republican party in recent years will hardly make that criticism. Nor is it just, if the view here taken of the present state of parties throughout the nation is correct. In that view, the rise of the Republican party in the South may be compared, in its potential effects upon our national politics, to the emergence of Japan into the field of international politics. The entrance of a new power may compel realignments of the old, with new alliances, 


\section{PRESIDENT TAFT'S OPPORTUNITY}

new policies; it may well mark the beginning of a new epoch in our political life.

To welcome the new is not to revile the old. If the South should to-morrow drop her guard, and throw away her shield, the act would imply no self-condemnation for the response she made to the desperate conditions which she faced forty years ago. If it be said that mere sentiment has governed her course, the answer is ready: mere sentiment is a nobler motive than mere self-interest. But sentiment has not been all : far from it. Interests more precious than are commonly debated in politics have seemed to force her into political isolation. Glorious as freedom is, it has often in history been accounted noble for men to deny themselves its fullness, and live withdrawn from power, and cabined from their fellows' emulations, when they have felt themselves custodians of some priceless heritage of principle; and this, beyond question, has been the South's own conception of her long recalcitrancy.

Yet it has cost her dear; and she, most of all, should welcome the new day - if this brightness is indeed the dawn. Her best minds have long yearned 


\section{PRESIDENT TAFT'S OPPORTUNITY}

forward to it, as to the day when they might keep faith with their country without disloyalty to their homes, to their race. Nor do they of that other race, because of whom there has been this long tribulation, desire that the new day shall not dawn. Their full hope, and the full hope of their champions, is yet denied. We have not gone beyond the modest hope of Lincoln. But at least that modest and reasonable hope is accomplished; and this achievement may prove the safe foundation of a greater hope. It will at least avail to fulfill Lincoln's prophecy. It will serve - in his own deep phrase - " to keep the jewel of liberty in the family of freedom."

1909. 
GREETINGS TO THE PRESIDENTS 



\title{
TO THEODORE ROOSEVELT
}

\author{
MARCH 4, I 909
}

COOD-MORNING, Mr. President! and, $\checkmark$ yes - au revoir! though not good-bye!

It is hard going to the side lines. You yourself never willingly made way for any one-except, perhaps, your successor. We wish we could leave out the "perhaps." But we are speaking candidly - so candidly that we will admit we find it hard to believe that even you never have longed for that which some often supremely desire-obscurity; some, indeed, so intensely that they would not envy a lion his morsel.

The "perhaps" must stay, and with it a thousand doubts. This question of what sort of man you are at heart has been, for years now, probably the commonest single topic of conversation in America. How you have become so conspicuous, so unavoidable, we think we can see. Decidedly you are not lazy. The thought of that incessant, demoniac energy of yours is to the indolent and 


\section{GREETINGS TO THE PRESIDENTS}

ease-loving among us like a lash. And in all your activity there is the instinct of success. Although you did not shine at school or college, you won from youth precisely the kind of training that counts in getting on. The very swiftness of your activities explains their success. And this goes deeper than it sounds. You act on first impulses, after a quick glance at situations, but with no more pondering than the average man will give. You thus, as a rule, hit upon courses which the average man - particularly the average man of affairs - is likely to approve. Of course, you have not time to ponder; but neither is that your bent. No act of yours has the quality of a work of patient art - as so many of Lincoln's had; nor has your speech the sweetness of meditation. Both suit newspapers better than they will suit books; but your countrymen read newspapers more than they read books.

This quality of your acts we cannot condemn. No mortal could give finish to all you do. But we do condemn the way you belabor us who do not totally approve - and praise - all you do. That is the most exasperating of your injustices. You tell 


\section{GREETINGS TO THE PRESIDENTS}

us vehemently how you and your friends value their honor above all things, and yet you freely and violently assail the good names of other men. Many you denounce for lying; yet it is the simple truth that thousands of your countrymen question your veracity.

For a while success threw such a glamour over you that we could only think of you as paragon or as arch-villain. It is curious how that illusion about men lifted up persists - when we know they must be like the rest of us. We do not believe all your opponents have been liars; nor yet that you yourself have been lying incessantly and consciously. It is plain that you put your side of everything too strongly. A whisper in the White House turns to thunder out of doors; but you have seemed to think you would not be heard unless you shouted. You are of those who use speech as means to all manner of ends. But even in this respect you may be a sign of moral progress; for even in this respect we must, we think, account you more scrupulous than Napoleon.

You will not wonder that we mention such a name. Many will. But you do indeed set us look- 


\section{GREETINGS TO THE PRESIDENTS}

ing for European counterparts. As a spectacle your career could stand a European, even an Asiatic, setting. In this you may have served us well. Europe seems to find you like her own rulers, to understand and respect your demonstrations of our strength. Nevertheless, you have more in common with Andrew Jackson, of Tennessee, than with Czar or Emperor. He, too, you remember, was violent in loyalties and hatreds. $\mathrm{He}$, too, kept his prestige to the end, and named his successor. Of course you are more than the frontiersman. City-bred and college-bred and traveled, you range beyond his narrow ken - and boldly essay full citizenship of every province your mind explores. But if you are more than he could be, may you not also be less? Can you match his sincerities - or his manners?

He was not a politician; and we long thought you were not. Now we know better. In politics, as in all things, you choose to win, with such devices as winning demands. You are right, we suppose, if life is. Going below these complex relations of men does not bring us to any countenancing by nature of abstentions in strife. You 


\section{GREETINGS TO THE PRESIDENTS}

despise the negative heroisms and moralities; we will not question whether you could attain them. With your doctrine and life principle of selfassertion, you have achieved a career in many ways splendid and glorious: we will not ask if you could have accepted a martyrdom, or lived through a life of self-abnegation.

Are there such lives? Sacrifice, humility, sometimes seem to us forms of self-seeking. The stormiest activity may be in truth a kind of yielding, as when Gladstone in agony turned from the church to the senate to work out a mystical consecration. Your ceaseless grasping at every means to achievement is compliance; there is in it what Swift called "the sting of perishable things." You are driven upon self-assertion as spirits equally ardent have been driven to the cloister.

It is yet too early to say what will be the permanent effect of your policies and methods on our actual constitution of government; or whether your party will hold to the course you have set it. The old questions of finance and the tariff you have left much as you found them. A true political instinct and sense of the movement of the 


\section{GREETINGS TO THE PRESIDENTS}

popular mind turned you instead to your resounding assault upon trusts, of which there is as yet no clear outcome. You are best out of doors. Coming generations will have most cause to think well of you when they take thought of things material: of deserts reclaimed and forests preserved, and the canal, perhaps, and the inland waterways. It is idle to inquire precisely how far these conserving enterprises are yours. You have successfully appropriated them, as you successfully appropriated certain policies of the party opposed to you. Such depredations are the rule in politics. Avoidances such as yours of the tariff are equally the rule. You have accomplished things which presidents of the older school would not have dared attempt, by methods they could hardly have imagined; and only time can determine which of your innovations will persist. You have excelled rather in the multitude of things done and striven for than in any kind of forbearance. In this, again, there is a kind of reassurance. Institutions which can permit such a man so much freedom, and which he yet does not obviously subvert, must have their roots deep in the popular conscious- 


\section{GREETINGS TO THE PRESIDENTS}

ness. They will long continue to set bounds to personal force in our public men. You have possessed and exercised our government; you could not, if you had desired and dared, have essentially altered its forms. Willingly or unwillingly, you have even respected, the mere tradition which denied you longer possession. What you have, in fact, seemed to demonstrate is that our system contemplates energy and aggression in its highest office.

Do you wonder that there is so little asperity in all this? We choose to be too serious for irony, or for that ridicule which you so constantly challenge and so frenziedly resent. Because it is the form of attack you resent least well, we discard it - to say au revoir. We can think of no other public man since Andrew Johnson so plainly pervious to gibes. That circumstance indicates, better, perhaps, than any other sign, the sense of you which will go into history. It will leave your eulogists free to compare you with Napoleon and Frederick the Great. It will debar them from associating you with that small group among the famous men of action whom a Voltaire or a Madame de Staël would have found it useless to assail, and who 


\section{GREETINGS TO THE PRESIDENTS}

would certainly never have persecuted any man or woman for pen-pricks. Hampden, we should say, was of that group, and Lincoln, and General Lee. For these were of those who have believed - we will not say rightly - that ruling one's own spirit is greater than taking cities; of those who practiced the emphasis of quietness. If you were set beside one of that group, before a Greek of the time of Pericles, he would see, better than we your countrymen can, wherein your success is failure.

We make concessions, Mr. President, - and we admit doubts. We are trying, in parting, to adhere to an attitude of sympathy. If we do not think we should have done so ill in your place, we are quite sure we should not have done so well. We are willing, if time shall prove your champion, to grow more and more reconciled into admiration. But we remember, or seem to remember, a kind of charm you had in years gone by which this so wonderful fruition of manhood does not yield; and we recall some words spoken by a young man as he parted from those same quiet places where your own youth was nurtured. He also be- 


\section{GREETINGS TO THE PRESIDENTS}

came a man of action - a soldier; he was the very man who fell

"Tipping with fire the bolt of men

That rived the rebel line asunder."

This is what he said: "Apollonius of Tyana tells us in his Travels that he saw ' a youth, one of the blackest of the Indians, who had between his eyebrows a shining moon. Another youth, named Memnon, the pupil of Herodes the Sophist, had this moon when he was young; but as he approached to man's estate its light grew fainter and fainter and finally vanished.' The world should see with reverence on each youth's brow, as a shining moon, his fresh ideal. It should remember that he is already in the hands of a sophist more dangerous than Herodes, for that sophist is himself. It should watch lest, from too early or exclusive action, the moon on his brow, growing fainter and fainter, should finally vanish, and, sadder than all, should leave in vanishing no sense of loss."

And yet - and yet - au revoir, Mr. President. Au revoir - but not good-bye. 


\title{
TO WILLIAM H. TAFT
}

\author{
MARCH 4, I 909
}

\section{CoOd-MORNING, Mr. President.}

J To you also we prefer to turn with serious eyes. Solemnities drop less naturally from our pen, we must own, in this greeting than in that tentative farewell we have just been pronouncing. We can imagine you saying what Charles Surface said while Sir Oliver paid his respects to Brother Joseph: "If they talk this way to Honesty, what will they say to me by and by?" And we could fall into that mood; for, strange to say, we seem less in doubt about you at your coming in than about this other at his going out. Certainly you do not suggest painful reflections on the mysteries of human nature and life and fate. Rather you invite to joviality and matter-of-fact.

But we are to watch your every act, listen to all your words, to praise and dispraise you, for four years, perhaps for eight. Frankly, we have much hope in you, and it is hard to believe we shall ever 


\section{GREETINGS TO THE PRESIDENTS}

feel bound to assail you with bitterness, to taunt, to deride. You have our liking - in common, we think, with that of nearly all your countrymen. But you know how hard it will be to keep from losing this well-nigh universal good-will. For Lord Russell was right, and the poet wrong. Government causes and cures countless ills. You cannot for a day exercise your vast powers without helping and hurting thousands. Wise or unwise, right or wrong, your acts will cut deep into human lives. We trust that you sleep well.

Frankly, again, there have been some things we do not like. Like your predecessor you in your youth revolted against that system of so-called protection which, in its present phase, we count an indefensible surrender, first of your party, and then of the government, to greed; and you, like him, have failed to defend in plain words this acquiescence of manhood against that rebellion of youth. When you touched upon your change of heart, speaking to young faces, in the place of your youth, your words went lame. You said then that you still approved of your youthful principles, that you held them still orthodox and sound - 


\section{GREETINGS TO THE PRESIDENTS}

"if only the application of them is not carried to such an extreme as to interfere with the public welfare." You certainly cannot believe that free trade or any other laissez-faire principles run riot in our present tariff laws. Now that you have declared yourself a protectionist, however, we will not ask you to act as if you had never ceased to be a free-trader. We sbould like you to study the life of Sir Robert Peel. But we will be content for the present if you will merely bring us back to protection - if you will merely insist that Congress shall squeeze the sheer robbery out of the schedules, although the real protection remains. All you have said since election day indicates that this is your purpose. Since you have progressed thus far, we have our hopes concerning the next step.

Frankly, again, we could wish there had been in your campaigns for the nomination of your party, and then for election, less apparent dependence on the help and favor of your predecessor. It gave, alike to your rivalry with other leaders in your own party and to your contest with the candidate of the opposition, a character not unexampled in our history. That Van Buren was similarly championed 


\section{GREETINGS TO THE PRESIDENTS}

has not been to his credit with historians. But we Americans understand personal loyalties, and respect them, too, when they do not mean disloyalty to principle or to us. Let us feel that in office you hold yourself responsible only to us and to principle, and we will not malignantly keep you in mind of the manner of your elevation. But we do not envy you the difficult choices you will have to make between independence and gratitude. There is but one safe rule, we think. Do the right, and be careless of interpretations. We shall probably understand and approve; but since you are only one man, charged with the interests of millions, it is not quite of the first importance whether we do you justice or not.

Frankly, again, we do not like your apparent participation in an insincerity which your party has too long practiced successfully. Every four years it goes before the country with words which can only be interpreted as a demand for interference by the Government of the nation between the two races now living together in great numbers in the Southern States; and yet, though in full control of all departments of that Government, your 


\section{GREETINGS TO THE PRESIDENTS}

party takes no such action as it seems to demand. We could dismiss the practice as harmless, since it deceives few; but lying is objectionable in itself. It is uncomplimentary in this instance to the intelligence of the country, and particularly to that of the unfortunate race most concerned. We believe you will in time set yourself against this practice.

For of the things we like there is none we like better than your impassioned declaration in the heat of your campaign that you did not wish to be President of half your country, and your decision to break all precedents of nearly half a century and go and offer yourself in person to our fellowcitizens of the South. We cannot help thinking that your thorough awareness of our place in the world as one great republic prompted you to this manliness and candor. We cannot afford to keep a Poland, an Ireland, in our system. But sheer sentiment played its part. You would be rid of the dominance of "old, unhappy, far off things." You know already how warmly the South responds to your challenge. We think we can assure you that your course has alienated no Northern friends worth keeping. 


\section{GREETINGS TO THE PRESIDENTS}

Of course the problem of the African in our body politic, as in our industries, our social relations, remains. You do not, we are sure, fancy you have solved it; nor are we ready to tell you how to solve it. We are not at all sure there is any solution, and fancy it may be misleading to use that word, or "problem," at all. What we have to do with is a situation, a condition, desperately permanent, yet measurably changing and changeable. No mere ingenuity will transform it. Evasion and dodging will not avoid it. Violence usually heightens the difficulties inseparable from it. It will always be in your power to stir its embers into angry flames; your power to alter it for the better is doubtful. We commend to you, therefore, the spirit and the methods, the infinite patience and sweet reasonableness, of that one among your predecessors who did, in fact, nevertheless deal with this perplexing situation more boldly than any one else ever did. You are less fortunate than he, in that to him it presented a reasonably plain question of right and wrong. You are more fortunate, in that you can freely take counsel with the true and accepted representatives of both these great 


\section{GREETINGS TO THE PRESIDENTS}

masses of human beings, who find their destinies linked together under our flag. We are confident that at least you will not, by flying in the face of facts, and contradicting racial human nature, aggravate what you cannot alleviate, merely disturb what you cannot change; yet that no force or agency which makes for human progress will find cause to upbraid you for coldness or neglect.

We are glad you have been a judge. Granting you consecration instead of ambition, we think you will find that to do justice among men will be your most constant function, though you wear no ermine. Our hope is the greater, because you have propounded no theory of life, profess no allegiance to any one principle in your own life, but have merely risen from task to task by virtue of efficiency and good nature. You will not set obiter dicta above decisions. The case itself will be your business, and you will wait for cases to come up before you decide them.

In nothing will that habit and procedure serve you better than in your effort, following your predecessor's lead, to make government stand for right 


\section{GREETINGS TO THE PRESIDENTS}

as between man and man, class and class, force and force, in all its relations to our appallingly complex industrial system. To proceed from one specific evil to another, to formulate no rules not based on actual experience, to try no mere experiments to go on step by step - this, simple as it seems, is the sole secret of England's success in free government. She arrives at generalizations only by amassing precedents. Her genius is the distrust of genius, and her caution and foresight consist in keeping pace with the demands of her civilization, not in running ahead to meet them.

It is better to go slowly than to go wrong. You do not possess, we do not think you imagine that you possess, the colossal genius to direct into new channels the immense social forces now contending on this continent as on others, to devise and impose a new plan for producing and distributing wealth. But you have the training and knowledge to correct abuses of the plan now in operation. At many points we have broken with the individualism of the past, though we once thought it the essence of our democracy. Perhaps we are moving toward socialism. If it is the best and final 


\section{GREETINGS TO THE PRESIDENTS}

form of society, however, we shall attain it without forcing our pace. We do not know our goal, and must yet hold fast to all that has proved soundest in our past experience.

Your limitations, therefore, commend you, Mr. President. Our greeting is the more cordial because we do not take you, and you do not take yourself, for a man of destiny; because we are not moved to make our salutation an obeisance.

Nevertheless, we commend to you all the inspiration to be got from considering the magnitude of your trust, the terrible height to which you are lifted up by our will and choice. Your station is like Cæsar's, or Charlemagne's. It is not less because railroad and steamship, electricity and the press, bring far things near and make the mysterious commonplace. Because you hold it, Europe and Asia are daily mindful of you. Maintain it, then, as we have no doubt you will, with dignity, and be conscious always that the great mass of your countrymen, of all races and parties and creeds, know instinctively the line between that criticism and opposition which a republic 


\section{GREETINGS TO THE PRESIDENTS}

permits and that which patriotism sternly forbids.

Good-morning, Mr. President — and good fortune! 


\title{
TO WILLIAM H. TAFT
}

\author{
MARCH 4, I 9 I 3
}

\section{Cood-Evening, Mr. President.}

$\checkmark$ And pray believe us when we assure you of the same hearty good will with which we bade you good-morning four years ago. You were then taking up the most difficult of rôles, and we sincerely wished you well in it. To-day, in laying down your great office, you are taking up a rôle almost equally difficult - that of a private citizen who has been President. In that rôle, too, we heartily wish you well.

More than that, Mr. President : the good will of a single journal is not important, but we are also convinced, strange as it seems in view of the overwhelming character of your defeat, that you still have the good will of the mass of your countrymen. Not of all, of course. You have been assailed with almost unexampled bitterness, and we cannot doubt that a considerable number of 


\section{GREETINGS TO THE PRESIDENTS}

your assailants sincerely felt the animosity they expressed. Perhaps we should go further still and concede that this animosity can by no means be attributed entirely to personal disappointments and resentments. Much of it doubtless comes of a respectable and citizenly disapproval of what, as President, you have done and failed to do. Nevertheless, we are quite sure that in respect of the real feeling of the mass of your countrymen toward you the tone of the press and other organs of public sentiment is a better criterion than the returns of the election. As you fortunately possess a sense of humor, we venture to assure you that we, the people, have voted you out of office with much the same friendliness with which we called you to our highest service.

Here, you will agree, is matter for reflection. An epigram promptly suggests itself: The man is popular, but not the President. But we do not like epigrams. They get rid of difficulties; they do not solve them. This one does not explain the disappointment of your Administration. For it has been a disappointment, a great disappointment. With your admirable candor you have 


\section{GREETINGS TO THE PRESIDENTS}

frankly told us that you yourself share with us all precisely that feeling about it.

Why, then, has it been a disappointment?

Assured of our liking, you will not resent our cognizance of the harshest view of the matter. Indeed, you have come near taking it yourself, for from the beginning you have expressed doubts of your fitness for the presidency, along with a preference for another kind of public service namely, the judicial. Looking at the matter broadly, we feel bound to agree with you, though we nevertheless admire rather than merely deprecate the several decisions you have made to go contrary to your own self-knowledge; for we believe that you took the presidency, as you took the governorship of the Philippines, from a sense of duty and not from preference. Still, we do agree with you, and mainly for the reason you yourself have given - to wit, that you are not a politician.

Do not mistake us; we mean no flattery; we use the word in its proper sense, and not at all as a term of reproach. For four years politics has been your business; and it is not a low business. 


\section{GREETINGS TO THE PRESIDENTS}

It is really a high and noble business. That low men, governed by low motives, constantly engage in it does not prove the contrary. The abuse of political skill by such men - the Cardinal Antonellis, the Marats, the Burrs and Quays and Platts makes no case against the splendid use of it, for the welfare of great communities, by the Cavours and Bismarcks, the Gladstones and Jeffersons and Lincolns.

That skill, that art, for it is an art, you clearly have not possessed. The want of it is quite as apparent in the most praiseworthy as in the least defensible of your presidential endeavors. When you set yourself to establish the entirely sound policy of reciprocity with Canada, you defended it with an indiscretion of speech that potently helped its enemies to defeat it. When, with the best of motives, you essayed to conciliate the South, you fatuously continued to listen to counsels which you should have known would be fatal to that patriotic enterprise. Worst of all, after fully committing yourself to the plan of an honest Republican revision of the tariff and leading the country to expect, as you yourself expected, 


\section{GREETINGS TO THE PRESIDENTS}

that it would be a revision downward, you put yourself and your policy into the hands of men whom every instinct of a true politician would have prompted you to distrust. Then you capped the climax by accepting, at the worst moment, the worst conceivable advice, and in violation of your own good nature, your own sense of justice, you used your power of patronage against men you should have trusted and in behalf of men who had undone you. It was a thing to make the angels weep. We cannot forbear reminding you - though perhaps you never knew it - of how, at that crisis of your career, we fairly went on our knees to you to take the opposite course.

It was lamentable. To great numbers of your countrymen it was also the cruelest of political surprises. For they had known you as an admirable judge; competent critics have said, a great judge. But to review action judicially, justly, is one thing; to use good judgment in the stress of action is another thing - and the higher of these two gifts you have not displayed. You have also failed to display certain other gifts that go to make a great Executive, a great man of affairs, a great 


\section{GREETINGS TO THE PRESIDENTS}

politician. You have shown good sense, but not inspiration; sound principles, but not the grand style in presenting and defending them; you have the power of clear and reasonable speech, but none of the eloquence that stirs the blood and moistens the eyelids; you win men's liking, but not their devotion.

And yet, by the irony of fate, it was your lot to face a situation from which only a very great politician could have emerged with credit! You were the leader of a party which had lost its pristine virtue, which had fallen under evil influences, which was already breaking into bitterly hostile factions. You were the chosen heir of a great political charlatan, who thus left you to face the dangers he had himself avoided; of a man who, having sown the wind, permitted you, in the name of friendship, to reap the whirlwind.

Well, you have reaped it; in the language of the street, which even Shakespeare sometimes found indispensable, you have "got what was coming to you." Your party is disrupted. Your administration is accounted a failure. And the man whom you thought your best friend, and 


\section{GREETINGS TO THE PRESIDENTS}

who had the most to do with your elevation, has sought to win his own way back into power on the strength of your discomfiture!

Why, then, do you ask, are not we also, and others like us, since we began as your good-wishers, now reproaching you? The best answer, $\mathrm{Mr}$. President, is the smile on your own lips, the twinkle in your eye, the undiminished sanity of your entire deportment. You have lost, but you are a good loser. You have been humiliated, but you have not whined or whimpered or sunk into melancholy. Best of all, you have not sought to throw the blame on your associates and subordinates. If you have failed as President, nevertheless, as an American man -

But no, the epigram is still misleading. Even as President you have had successes. Even when, as President, you have seemed to fail most obviously, there is room to question whether the failures may not have been in some measure only apparent, only temporary. You did not persuade your party to revise the tariff honestly; in the crucial moments of that struggle you were pitiably hoodwinked. Nevertheless, you have faced 


\section{GREETINGS TO THE PRESIDENTS}

the issue, you have not run away from it; and therefore the reform is imminent. In that regard the outcome of your leadership still permits, as its beginning suggested, a comparison with $\mathrm{Sir}$ Robert Peel's. Seemingly, you have failed, too, in your still more commendable endeavor, steadfast and long continued, to quiet the mood of wild expectation in which, by the extraordinary vagaries of your predecessor, your countrymen had been left. That mood still prevails; there is still danger that it will, before it wanes, do some damage to our institutions. But your steadfastness in sanity has not been altogether wasted. What is left of your party still stands for preservation, not for destruction, for sense and not for sheer and unruled impulse. Even in the loftiest and boldest of your enterprises, you have not failed entirely. The arbitration treaties are indeed emasculated; we do not wonder that you hesitate to sign them. But they are not dead. It is quite believable that a century hence they will be accounted the beginning of the world's permanent peace. The glory of it will be America's, even if it is not yours.

In all probability glory will not be your por- 


\section{GREETINGS TO THE PRESIDENTS}

tion, Mr. President. We are speaking with entire candor and that is our impression, as it is also, quite likely, your own. Still, we know what changes time can work concerning the esteem of Americans for their Presidents. It is even now working a great change concerning the reputation of your unfortunate Ohio predecessor, President Hayes. To the multitude his name is still a signal for ignorant depreciation. Nevertheless, to the trained and competent historians who are beginning to review his administration he appears more and more as a man greatly underestimated, as a President who, notwithstanding the cloud which will always rest upon his name, rendered to the American people services that are simply incalculable. He was the true initiator of civilservice reform; he was the first President after Lincoln who honestly tried to treat the Southerners as his countrymen.

But we forbear, Mr. President; the worst of Job's afflictions was his comforters. What we had in mind to do was not to offer you smelling-salts, nor yet to read you lectures, but to make you our respects. 


\section{GREETINGS TO THE PRESIDENTS}

You have chosen, wisely we think, to become a teacher of young Americans, and you are amply equipped for your new duties. You will not, we are confident, teach them bitterness. You will not sully their "white shields of expectation." You will, on the contrary, try to prepare them to do their best cheerfully, in all circumstances, for their country. Nevertheless, there will come at times, in spite of all your good nature, intervals of austerity. For you have walked the heights of human destiny; you have sounded the depths of human meanness and depravity. Sometimes, beyond your smile, you will wear that air of "grave and melancholy reflection" which Macaulay praised in Thucydides. And it will be well. It will be well that these young minds shall learn from you, though you will not wish to teach it, something of the human weaknesses that lead to great disasters, something of the baleful human passions that keep us all, nations and men alike, forever on the verge of tragedy. 


\title{
TO WOODROW WILSON
}

\author{
MARCH 4, I 9 I 3
}

\section{COOD-MORNING, Mr. President!}

$\mathcal{J}$ To you, indeed, it hardly seems needful that this journal should offer assurances of its own good-will and good wishes. In all its life no political enterprise has ever engaged its sympathies more deeply than that which ends to-day as you take your solemn oath of office. But to you, too, we can offer whatever heartening there may be in our conviction that you also have the good-will and the good wishes of the majority of Americans.

We have no fear, Mr. President, that you will overestimate the value of our own or any other assurances in that matter; even if you agree with them, you will not vainly imagine that your present great prestige and popularity are a secure possession. For we feel sure that you are not politically short-sighted. We feel sure that you do not need to be told that the more auspiciously a man enters upon a great trial of his quality the more he has to 


\section{GREETINGS TO THE PRESIDENTS}

fear from anything like failure to meet it worthily. You have shown convincingly that you understand the incessant nature of democracy's demands and the necessity of meeting them continuously, unfalteringly - of fighting all one's battles through, as Grant said - if one would survive politically.

In that clear-eyed envisagement of obligations and of dangers we find, indeed, one of the chief sources of our hope in your administration; for we regard it as one of the many proofs of your political competency.

On this point, no doubt, we differ with many other observers of your career. For we do not in the least share the apprehension that your long years of devotion to academic tasks will be found to have dimmed your eyes to harsh realities. On the contrary, we take comfort from the circumstance that you have all your life been studying in quiet such problems as now confront you, such careers as you yourself are now attempting. We are happy to feel that, like most Americans, but unlike your immediate predecessor, you like politics; that you understand politics; that you have already proved yourself an excellent politi- 


\section{GREETINGS TO THE PRESIDENTS}

cian. We shall be disappointed if, before the end, you shall not have proved yourself a great politician.

So shall we all be, Mr. President, and so will you be ; for none of us has indicated a clearer comprehension than you have indicated of what the times and the country's mood really demand of you. Administrative skill, executive efficiency - these, of course, are always demanded of a President. But you know that to-day, for you, they will not be enough. You know that you face a crisis; that you may, quite conceivably, inaugurate an epoch. Before we take up, with other journals, our constant duty of unsparing criticism, perhaps you will permit us briefly to indicate what we conceive your full task and opportunity to be.

It is to lead democracy in a fresh advance which it now clamors for. It is to guide democracy wisely while it compasses and overcomes a new kind of opposition that for some generations has been erecting itself among us; a kind of opposition to democracy which is all the more baffling and confounding because it is, in the main, an outcome of democracy itself; because it is as if, in our startled 


\section{GREETINGS TO THE PRESIDENTS}

battling with it, a giant strove with his own giant offspring. In this respect the curious instinct of the cartoonists is no false leading, but a true indicator of our real predicament. For the real foe of democracy in this country wears no form that privilege has ever worn before. It is not monarchical, it is not aristocratic, it is not military, it is not clerical. It is entirely economic and industrial. The seat and source of it is neither court nor camp nor church; it is the common market-place. The essence of it is, to be sure, monopoly, and monopoly is old. But this kind of monopoly, self-created and self-sustaining monopoly, is new. It is young and vigorous. Of all the forces that make against democracy it is the youngest and most vigorous now extant in the world.

That is your giant antagonist, Mr. President; and democracy expects of you nothing less than that you forthwith prove yourself its Jack the Giant Killer.

A great expectation, truly! For the movement you must head, like most of democracy's periodical uprisings and self-assertions, is vague and instinctive, as well as tremendous. But we cannot 


\section{GREETINGS TO THE PRESIDENTS}

doubt that you both comprehend its sweep and are striving to find for it definite aims and reasonable methods. Fortunately, you are in deep sympathy with it; otherwise you could never hope to guide it. But fortunately, too, you have yourself written the history of another very similar movement - the movement by which the people, with Andrew Jackson leading, once before "took possession of their government." Turn to the skillful phrases in which you yourself have pictured that advance, estimated alike the gains and the costs of it, praised and blamed its leadership, and you will find there many a true word and many a sound reflection that should to-day be helpful to you and to your fellows in leadership. For the present age seems plainly to demand of you that in many respects you be like Jackson. But it is a later age; may it not therefore demand more? You have had a better training than Jackson's, and no such harsh, embittering antecedents; may we not, therefore, expect of you less of error and violence and excess, and more of restraint and of just consideration and calm foresight, yet without loss of firmness in essentials? 


\section{GREETINGS TO THE PRESIDENTS}

Yes, Mr. President, it is a great expectation, a daunting expectation. We should be insincere, we should be merely flattering you - or any other man alive, for that matter - if we pretended an absolute assurance of your proving entirely equal to it. It is enough that, like your party and like the country, we should account you, of all men visible now to the nation, the man most likely to prove equal to it.

We do not neglect to note your handicaps; we shall not forget them when we fall back into our ordinary function of watchfulness and criticism. It was your immediate predecessor's misfortune to lead a party which had been too long in power; it is your misfortune that you lead a party which has been too long out of power. It lacks the training power alone can give. It has the habit of irresponsible protest and criticism, not of responsible action. You will besurrounded by men whocan speak only from conviction, not from experience. To keep your leadership you must be, perhaps, complacent with ignorance and prejudice. Do not, we beseech you, be too complacent; for that may prove your greatest danger. We do not underestimate the 


\section{GREETINGS TO THE PRESIDENTS}

necessity of tact and consideration and whatever else may make for harmony, but we would, nevertheless, fortify you in loyalty to your own superior training and instincts. For it must be with you as with every other man lifted up to high place and great power. There is no way to spare you the duty of self-reliance; there is no way to spare you the loneliness of your great station. If you relieve it with a kitchen cabinet, we, for one, shall not be too censorious.

Your party is also hungry, for it comes in from a long wandering in the desert, and from this cause, too, you will face temptation and must endure a wearying importunity. More than that: because your party is unaccustomed to power, it will not be at ease in power. Part of your great task in leadership will be to teach it self-confidence; yet it will be equally necessary to hold it back from over-confidence and extravagance. There will inevitably be required of you a constant and supremely difficult balancing of restraint and energy, of sympathy and steadfastness, of courage and caution. For the full test of you and your party will be nothing less than this: that through you democracy 


\section{GREETINGS TO THE PRESIDENTS}

shall win victories and yet shall not abuse them.

But if, Mr. President, we are thus candidly mindful of all that confronts you, we are also happily mindful of much, of very much, to hearten and to help you. Happily for you, as for us all, you are the choice of no one section, but of the whole country. As your elevation excludes no one section from power, you will escape a kind of bitterness that has borne hard on many of your predecessors; and yet you will not lack the fine inspiration to be drawn from the peculiar pride in you of a particular section, a section strong in loyalties. Southern-born, it is your privilege to restore the South to a full share in the country's affairs, to help her prove her fitness for it, and to revive, let us hope forever, the great tradition of her spacious patriotism in the early days of the Republic.

Less than this, perhaps, but far from little, will be the inspiration of your academic memories. At every crisis there will be the inspiring consciousness that to an extraordinary degree you represent in American public life the training and ideals of American colleges. There will be something still 


\section{GREETINGS TO THE PRESIDENTS}

more poignant - the passionate, intimate appeal of your own ancient university, calling upon you, as with bells and songs, to win for ber still greater honors. If need be, alma mater may serve you better still. If the worst comes to the worst, if the path of duty becomes the way of sacrifice, if it so happens that you must lay down even popularity itself on the altar of patriotism, you can still see the tall tower with which she commemorates that other President of whom, in the hour of his seeming failure, you yourself wrote: "The men who assess his fame in the future will be no partisans, but men who love candor, courage, honesty, strength, unshaken capacity, and high purpose such as his."

Yes, Mr. President, the task is great, the dangers manifold, and manifold the temptations. But all your youth will now, surely, rise up and reinforce your manhood. The great thing has happened has happened to you, of all men. Surely you will not quail before it. Surely you will not lack in the face of opportunity and of danger the supreme human quality; you will not lack courage - the kind of courage that is one with sincerity. As you 


\section{GREETINGS TO THE PRESIDENTS}

go to meet Fate's call, the time's demand, your country's summons, your mood will not be one of pride or self-sufficiency; yet surely it will be as if, in your own heart, a drum beat, or a trumpet sounded.

THE END 


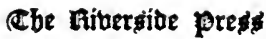

CAMBRIDGE - MASSACHUSETTS

U.S.A 

UNIVERSITY OF CALIFORNIA LIBRARY, LOS ANGELES

\section{COLLEGE LIBRARY}

This book is due on the last date stamped below. 

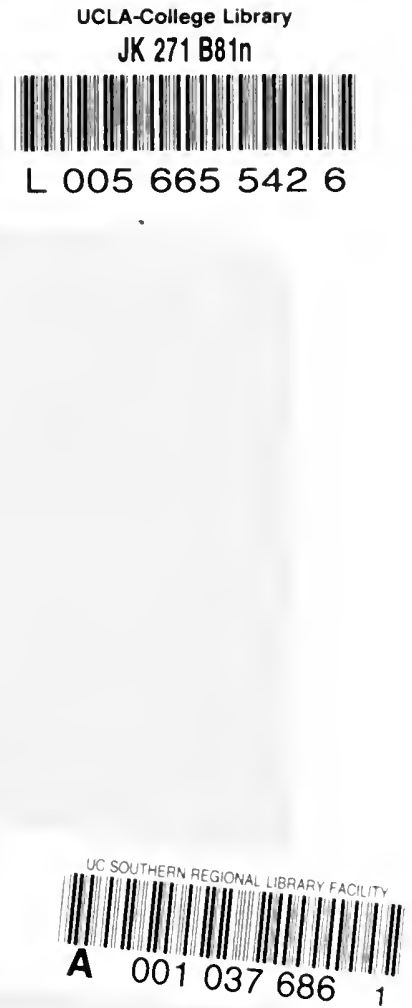
